Document downloaded from:

http://hdl.handle.net/10251/50792

This paper must be cited as:

Pulido Velázquez, D.; García-Arostegui, J.; Molina González, JL.; Pulido-Velazquez, M. (2015). Assessment of future groundwater recharge in semi-arid regions under climate change scenarios (Serral-Salinas aquifer, SE Spain). Could increased rainfall variability increase the recharge rate?. Hydrological Processes. 29(6):828-844.

doi:10.1002/hyp.10191.

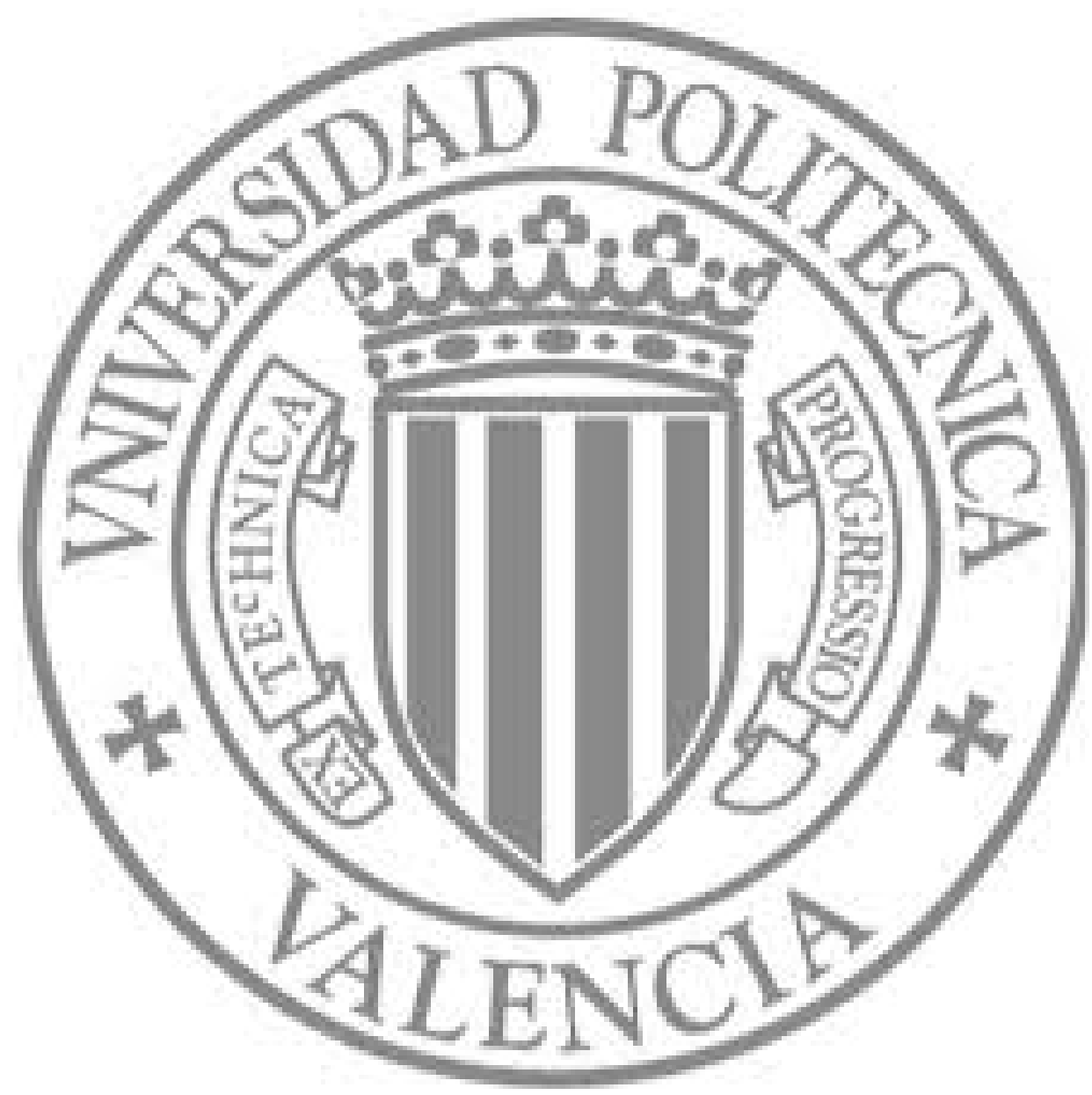

The final publication is available at

http://dx.doi.org/10.1002/hyp.10191

Copyright Wiley 


\title{
Assessment of future groundwater recharge in semi-arid regions under climate change scenarios (Serral-Salinas aquifer, SE Spain). Could increased rainfall variability increase the recharge rate?
}

David Pulido-Velazquez ${ }^{(\mathrm{a}, \mathrm{e})}$, José Luis García-Aróstegui ${ }^{(\mathrm{b})}$, Jose-Luis Molina $^{(\mathrm{c})}$, Manuel Pulido-

$$
\text { Velazquez }^{(\mathrm{d})}
$$

(a) Corresponding author. Geological Survey of Spain (IGME). Granada Unit; Urb. Alcázar del Genil, 4. Edificio Zulema. 18006. Granada, Spain. E-mail: d.pulido@igme.es; Phone: +34- 963943 474, Fax -963 944436.

(b) Geological Survey of Spain (IGME). Murcia Unit; Avda. Miguel de Cervantes, 45 5॰ A. Edificio Expo Murcia, 30009 Murcia, Spain. E-mail: j.arostegui@igme.es

(c) Salamanca University. High Polytechnic School of Engineering Avila. Department of Hydraulic Engineering. Av. de los Hornos Caleros, 50, 05003, Ávila. E-mail: jlmolina@usal.es

(d) Research Institute of Water and Environmental Engineering (IIAMA), Universitat Politècnica de València, Camino de Vera s/n, 46022 Valencia, Spain E-mail: mapuve@hma.upv.es

(e) Departamento de Ciencias Politécnicas, Escuela Universitaria Politécnica, UCAM Universidad Católica San Antonio de Murcia, España.

\begin{abstract}
The projected impact of climate change on groundwater recharge is a challenge in hydrogeological research because substantial doubts still remain, particularly in arid and semiarid zones. We present a methodology to generate future groundwater recharge scenarios using available information about regional climate change projections developed in European Projects. It involves an analysis of Regional Climate Model (RCM) simulations and a proposal for ensemble models to assess the impacts of climate change. Future rainfall and temperature series are generated by modifying the mean and standard deviation of the historical series in accordance with estimates of their change provoked by climate change. Future recharge series will be obtained by simulating these new series within a continuous balance model of the aquifer. The proposed method is applied to the Serral-Salinas Aquifer, located in a semi-arid zone of SE Spain. The results show important differences depending on the RCM used. Differences are also observed between the series generated by imposing only the changes in means or also in standard deviations. An increase in rainfall variability, as expected under future scenarios, could increase
\end{abstract}


recharge rates for a given mean rainfall because the number of extreme events increases., For some RCMs, the simulations predict total recharge increases over the historical values, even though climate change would produce a reduction in the mean rainfall and an increased mean temperature A method based on a multi-objective analysis is proposed to provide ensemble predictions which give more value to the information obtained from the best calibrated models. The ensemble of predictions estimates a reduction in mean annual recharge of $14 \%$ for the scenario A2 and 58\% for the scenario A1B. Lower values of future recharge are obtained if only the change in the mean is imposed.

Keywords: climate change, groundwater resources, groundwater recharge, future scenarios, semi-arid regions

\section{INTRODUCTION}

Nowadays, despite some uncertainties, there is certain consensus that the planet is undergoing a cycle of climate change in which Man's activities are the main driving force. The most recent IPCC report does not talk of certainty, but rather that there is a $90 \%$ probability that this is so (IPCC, 2007). The most recent studies on climate change project significant declines in water resources in Mediterranean catchments, producing significant environmental, economic and social impacts (Iglesias et al., 2007). However, despite recent developments in climate modelling, as global circulation models and techniques of dynamic and statistical rescaling (Fowler et al., 2007), the following statement continues to be valid, even twenty years after it was first made: "scenarios are not meant to be predictions of future climate; rather they are meant to be internally consistent pictures of a plausible future climate, a basis for other workers to evaluate the possible impacts of climatic change on Man and society" (Wigley et al., 1986, cited by Dragoni and Sukhija, 2008).

Although a large number of much research studies has been aimed at developing methods to analyse downscaling scenarios for climatic variables to smaller cells, less attention has been paid to downscaling for examining the impacts of climate change on water resources systems in terms of runoff or groundwater recharge (Fowler et al., 2007b; Cayan et al., 2008; PulidoVelazquez et al., 2011). Most climate change studies have focused on the impacts on surface 
water resources (Lautenbach et al., 2009; Bell et al., 2007). In the majority of these studies, future inflows are generated on a monthly scale by altering the natural historical series in accordance with a plausible monthly variation for the future, deduced from climate model simulations in the study area. In most cases, the historic inflow series are scaled by multiplying them by a response ratio (e.g., Zhu et al., 2005). This modifies the mean according to the change in mean deduced from climate models in that zone. In contrast, Hernandez-Barrios (2007) used monthly response ratios to alter natural rainfall and temperature series, modifying their mean in accordance with climate model predictions, and, then, introducing the results into a calibrated rainfall-runoff model of the basin to obtain the future inflows. In some systems, however, climate change could significantly modify not only the mean, but also the standard deviation of streamflow, and this change in variability could have an influence on future management problems and their possible solutions. Pulido-Velázquez et al. (2011) developed a procedure to generate future inflow series which consists of altering historic series by incorporating not only the change in mean, but also the change in standard deviation deduced from climate model simulations. Other authors (Bouraoui,et al. (1999) and Candela et al. (2009), etc) have employed local whether generator to define future scenarios for a water resources system taking into account the change in mean and standard deviation in rainfall and temperature. They need to calibrate a stochastic daily rainfall model and a stochastic daily temperature model. The future series are obtained by perturbation of the parameters of the stochastic models in accordance with the relative change in monthly mean and standard deviation deduced from a General Circulation Model (GCM).

Although IPCC (Parry et al., 2007) and FAO (2008) were recently highlighting the paucity of research into groundwater resources and climate change, the number of research papers dealing with the sensitivity of groundwater systems to climate change has grown fast in recent years, as shown in recent review papers such as Green et al. (2011), presenting scientific issues and methods for global change assessment on groundwater, Treidel et al.(2012), where a number of case studies from Unesco-GRAPHIC programme are presented, or Klove et al. (2013), which examines climate change effects on groundwater and dependent ecosystem, future threats and research gaps. The predicted changes in temperature and rainfall can have significant impacts on aquifer recharge (Jyrkama and Sykesa, 2007) and lead to marked variations in hydraulic heads. This could affect the availability of water resources, modify the relationships between surface and groundwater bodies, affect pumping costs and even induce aquifer pollution. Green et 
al. (2011) reviewed studies on the impact of climate change on groundwater recharge, concluding that "climate change and variability will likely impact on numerous recharge rates and mechanisms" (Vaccaro, 1992; Green et al., 2007; Kundzewicz et al., 2007; Aguilera and Murillo, 2009). Many climate-change studies have predicted decreases in aquifer recharge (Merritt et al., 2006; Herrera-Pantoja and Hiscock, 2008), whilst others predict an increase in aquifer recharge under certain conditions and during certain periods (Yusoff et al., 2002, Green et al. 2007; Jyrkama and Sykes, 2007; Kovalevskii (2007); Döll, 2009; Gurdak and Roe, 2010).”

In this paper we propose a methodology for analysing the impacts of climate change on aquifer recharge using climate change scenarios developed in the framework of the European projects PRUDENCE (2004) and ENSEMBLES (2009). The aim of the present work was to study the sensitivity of results when not only the change in mean rainfall and temperature are incorporated, but also the frequency of rainfall events is considered. It is of special interest in semi-arid regions where rainfall is expected to become more variable. Aquifer recharge rates would be expected to rise in semi-arid areas, while greater variability in humid regions would decrease aquifer recharge rates as more water is lost to runoff (WRF, 2009). The method includes a simple downscaling technique that allows this analysis to be performed (Pulido-Velazquez et al., 2011). The methodology has been applied using different time scales in the Serral-Salinas aquifer. It has allowed deductions to be made about the requirements that the rainfall and temperature series should satisfy in order that the proposed downscaling technique can be implemented. The study also includes an analysis of potential hydrological impacts of climate change on the aquifer system under two emission scenarios (A2 and A1B).

The paper is structured as follows: Section 2 considers the methodology and techniques employed. Section 3 is an overview of the case study and the recharge model. In section 4, the methodology is applied to the case study and the results and discussion are outlined. Section 5 describes the limitations of the methodology. Finally, section 6 summarises the main conclusions and the expected future improvements.

\section{METHOD}

A method for assessing the impacts of climate change on groundwater recharge in an aquifer system based on available historical climate series together with data on the effects of climate change in the area (area information superimposed on RCM simulations) is proposed (Figure 1). 
It includes the next steps: (1) analysis and comparative assessment of regional climate models (RCMs) projections according to their ability to reproduce historical climatology in the system, and proposal for creating an ensemble of models; (2) generation of precipitation and temperature time series spatially disaggregated for the system using the proposed downscaling technique on an appropriate spatio-temporal scale for the subsequent assessment of impacts; (3) assessment of the impact of climate change on aquifer recharge by simulating the new climate conditions in a calibrated continuous balance model. We attempt to evaluate the sensitivity of recharge to the incorporation not only of the change in the intensity of the climate series but also in the frequency of extreme events.

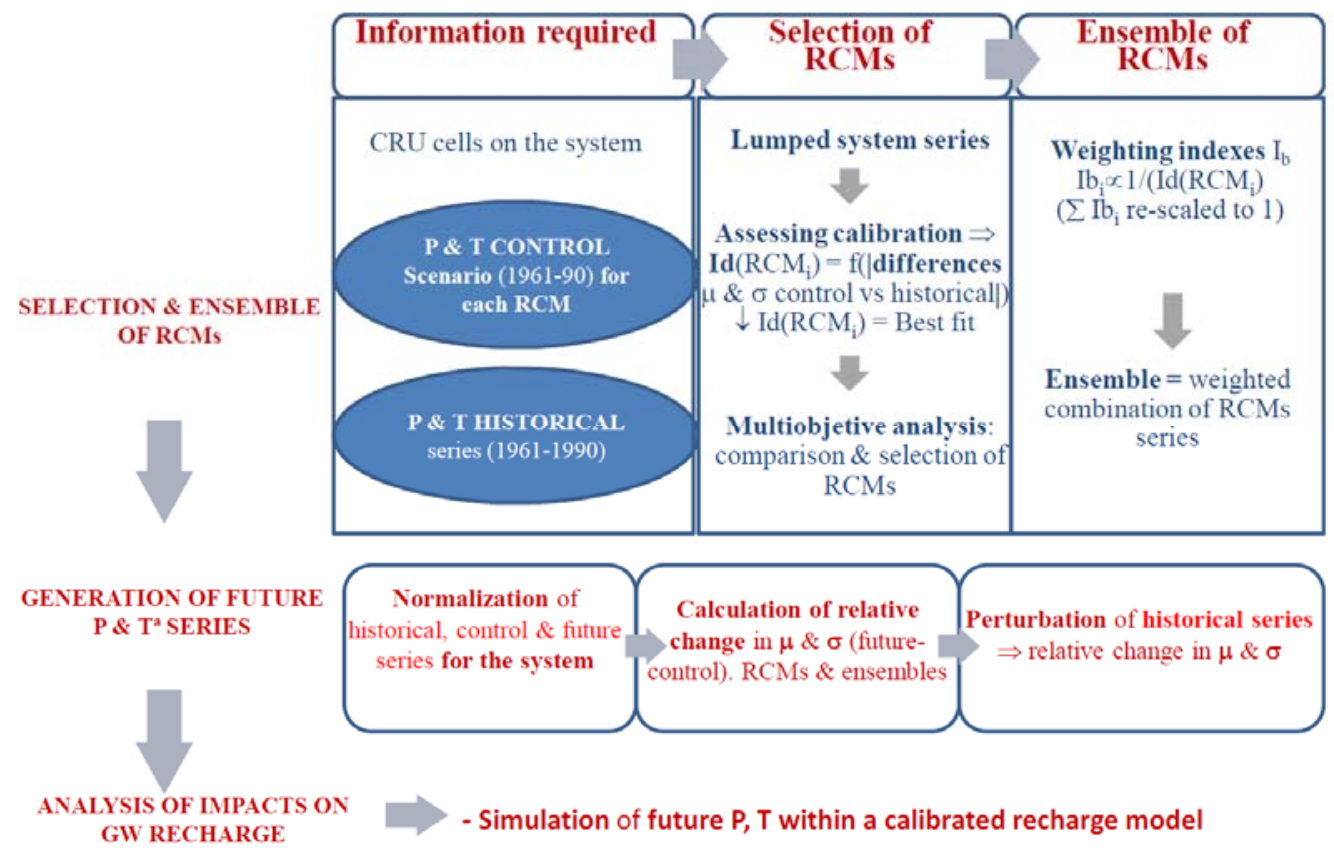

Figure 1. Scheme of methodology

\subsection{Analysis of RCMs and proposal for ensemble models.}

The ability of RCMs to reproduce the historic climate of the study area has been assessed. We have used information of the EU projects PRUDENCE [2004] and ENSEMBLES [2009], data publicly available on the project websites: http://prudence.dmi.dk/ and http://ensembleseu.metoffice.com/. Both sites allow the "control series" to be downloaded for simulations produced by various regional climate models over the period 1961-1990 for the study area. In 
order to evaluate the goodness of the calibrations obtained with each RCM, key statistics are compared for the mean year on a monthly basis for both, the control series derived from the RCM and the historical series over the same period (1961 -1990). The comparison was carried out using variation in means and standard deviations, since we will use the expected changes in these statistics for the generation of future time series (see section 2.2). To facilitate this analysis, both the historical series (downloaded from http://badc.nerc.ac.uk/data/cru/; see Haylock et al., (2008) for a detailed description of this historical series) and the control series for the study area were downloaded onto the same universal grid proposed by the Climate Research Unit (CRU) grid, with a spatial resolution of 50x50 km.

The goodness-of-fit obtained using each RCM for the mean and standard deviation of $\mathrm{P}$ and $\mathrm{T}$ was assessed by an indicator (Id), which is defined as the sum (for the twelve months of the mean year) of the absolute value of the relative distance between the statistics derived from the historical and control time series (Eq. 1).

$$
I d_{i}=\sum_{n, m=1}^{2} I d_{i}\left(V_{n} S_{m}\right)
$$

$I_{i}\left(V_{n} S_{m}\right)=\sum_{j=1}^{12}\left[\left(V_{n} S_{m}\right)_{i}^{j}-\left(V_{n} S_{m}\right)_{\text {Hist }}^{j}\right] /\left(V_{n} S_{m}\right)_{\text {Hist }}^{j}$

Where ${ }_{i}=$ subindex employed for a specific $\mathrm{RCM}\left(\mathrm{RCM}_{\mathrm{i}}\right) ; V_{1}=$ rainfall variable; $V_{2}=$ temperature variable $S_{1}=$ mean monthly value; $S_{2}=$ monthly standard deviation; ${ }_{j}=$ months for a mean year.

On the basis of the values taken by these four Id indicators for each RCM, corresponding to mean and standard deviation of both the precipitation and temperature series, we undertook a multi-objective analysis for each RCM to identify which models were "inferior" in terms of goodness-of-fit to the observed time series (dominated solutions, using terminology of multiobjective analysis) and which models fall outside of the threshold limits. Eliminating these "dominated" models, the remaining models are used to define a new global index (Ib') which is the sum of the Ip indices for each model. This indicator allows a ranking of RCMs to be established based on the calibrations obtained, so that ensemble of predictions can be proposed, which gives more weight to the series generated from the best calibrated RCMs, which, a priori, 
should inspire more confidence in their predictive power. Thus, the index Ib' can be rescaled defining the index $\mathrm{Ib}^{*}$, whereby the sum of the values obtained for all the models corresponding to the same emission scenario is equal to 1 . The values complementary to the index $\mathrm{Ib}^{*},\left(1-\mathrm{Ib}^{*}\right)$ rescaled to 1 (index Ib) will be used as the weight applied to the series obtained with each model to create an ensemble of predictions, so that the better calibrated models (the models that fit better to the historical series) have greater influence. These "ensembles" coalesce and consolidate the results of individual projections so allowing more robust projections that are more representative than those based on a single model (AEMET, 2009). The weights of members of an ensemble are an active research topic and there is not yet sufficient consensus on its practical application (Lopez et al., 2009, Christensen and Lettenmaier, 2007). In fact, in most operational implementations for probabilistic forecasting, both in the short and medium term, all the members of the ensemble are considered equiprobable (AEMET, 2009).

\subsection{Generation of future climate series and downscaling technique proposed}

The aim is to generate future time series for precipitation and temperature in the system in order to assess how the change not only on the mean but also on the variance of the precipitation and temperature series impact on the resulting groundwater recharge. We aimed to achieve this based on available information on climate scenarios generated in Europe using regional climate models (RCMs) in the PRUDENCE and ENSEMBLES projects. For different RCMs, monthly and daily precipitation and temperature series were downloaded for the control scenario (defined for the 30 year period [1961-1990] of historical situations) and for various climate change scenarios (future series simulated under certain climatic conditions). Future scenarios correspond to the results derived for a specific horizon based on RCMs simulations under different emission scenarios. The spatial resolution of the series used varies from $22 * 22 \mathrm{~km}$ to $50 * 50 \mathrm{~km}$ depending on the regional model. This spatial resolution may be too coarse to study the climatic and hydrological impacts on an aquifer system. Logically, when studying the impacts and adaptation strategies in an aquifer system, the historical hydrological situation has to be characterised by the level of spatial detail appropriate for the particular case and the data available. The climatology of the system is also reproduced with greater spatial detail and greater spatial accuracy with the completed historical series, to build a simulation model or system management model (hereafter 
referred to as the "original climatic series") which uses information directly extracted from the RCMs control scenarios.

In order to analyse the effect of climate change on a system, we propose to apply a "deltachange" approach to the "original climate series" by modifying the mean and standard deviation according to the RCMs simulations for the study zone. In this way, the RCMs results will be used only for estimating the relative change expected for the zone for each of the climate variables, avoiding the use of the absolute value they provide. To do this, an analogue procedure developed in Pulido-Velazquez et al. (2011) is proposed to correct series of historical inflows:

1) Aggregation of the original rainfall and temperature series of the system to define single global series $y^{x \cdot j}(O)$, where $x$ varies from 0 to $X-1$ ( $X$ being the number of years in the series) and $j$ varies from 1 to 12 , representing the 12 months of the year. Thus, the product $x \cdot j$ represents the number of months in the series. $(O)$ is employed to indicate that we refer to the original (natural) series.

2) Identification of the cell of the RCM grid where the system is located to obtain the monthly mean $\left(\mu^{j}\right)$ and standard deviation $\left(\sigma^{j}\right)$ values of the RCM series $y^{x \cdot j}(s)$, where s can adopt one of two values, 1 for a control scenario and 2 for a future scenario.

3) Normalization of the control and future series $y^{x \cdot j}(s)$ using $\mu^{j}(s)$ and $\sigma^{j}(s)$. The normalized series will be:

$$
y_{N}^{x \cdot j}(s)=\left[y^{x \cdot j}(s)-\mu^{j}(s)\right] / \sigma^{j}(s)
$$

4) Change in the mean and the standard deviation, respectively, will be given by:

$$
\Delta \mu^{j}=\left[\mu^{j}(2)-\mu^{j}(1)\right] \mu^{j}(1) \text { and } \Delta \sigma^{j}=\left[\sigma^{j}(2)-\sigma^{j}(1)\right] / \sigma^{j}(1)
$$

5) The single global series modified to take into account the effect of climate change $\left(y^{x \cdot j}(C)\right.$, where $(C)$ is employed to indicate that we refer to the climate change streamflow series) will be:

$$
y^{x \cdot j}(C)=\sigma^{j}(C) \cdot y_{N}^{x \cdot j}(O)+\mu^{j}(C)
$$


where $\sigma^{j}(C)=\sigma^{j}(O) \cdot\left(1+\Delta \sigma^{j}\right)$ and $\mu^{j}(C)=\mu^{j}(O) \cdot\left(1+\Delta \mu^{j}\right)$, being $(O)$ employed to indicate that we refer to the original series.

The procedure has already been applied to a case study in Spain to alter the monthly time series of historical inflows at catchment scale. However, its application in aquifers for generating future daily series has not been explored. The current research study analyses the applicability of this methodology for generating series of daily precipitation and temperature.

\subsection{Evaluation of the impact of climate change on groundwater recharge}

The impacts of climate change on groundwater recharge in the aquifer system will be quantified by simulating the new precipitation and temperature series corresponding to future scenarios using a continuous balance model that has been previously calibrated for the aquifer (Molina et al., 2009, 2011 and 2013).

Regarding the spatial detail of recharge models, these can be classified as either lumped parameter models or distributed models. The lumped models use few parameters to simulate the behaviour of the system as a whole. These models do not allow the spatial variability of the climate and hydrological variables to be represented, nor the physical behaviour of the system (spatial variability of parameters relating climatic and hydrological variables). Similarly, in order to assess the spatial variability of the effects of climate change and the impacts on aquifer recharge, the use of a distributed recharge models is required.

\section{CASE STUDY AND RECHARGE MODEL}

The present study is focused on one of five most highly ranked depleted aquifers of the World (the Altiplano of Murcia, Spain; Werner et al, 2013), specifically on the Serral-Salinas aquifer, located between the Murcia and Alicante provinces (Figure 2). The region experiences a mild Mediterranean climate. In general, current demand greatly exceeds available supplies, and water is an issue of paramount importance. From a hydrologic standpoint, the area has no permanent surface water bodies, the only available water is that obtained from exploitation of aquifers, and the region has not formed part of any of the large hydraulic projects that have been carried out in SE Spain like Tajo-Segura water transfer. The impacts of pumping from the SerralSalinas aquifer extend to the regional scale, well beyond the boundaries of the aquifer area 
(Molina and García-Aróstegui, 2006, 2007). Responsibilities for the monitoring of the aquifer are shared between the Júcar and Segura River Basin authorities.

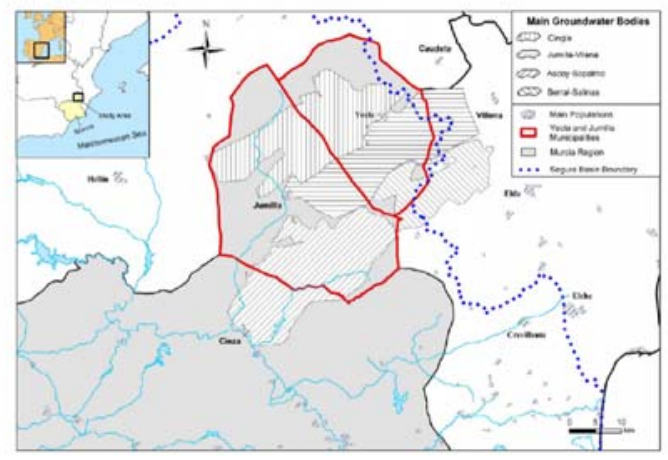

Figure 2. Location map of the study area

The historical overexploitation of the Serral-Salinas aquifer has severely affected its hydraulic behaviour. Mean renewable groudwater resources in the aquifer are estimated to be about five million of cubic meters per year, derived exclusively from the infiltration of rainfall onto permeable outcrops (Molina et al., 2009). Pumped abstraction can only be estimated indirectly, as very few boreholes are equipped with volumetric control meters. The volume and rate of water abstraction is estimated from bibliographic records and from field surveys on the main water users. The average rate of exploitation over the last 10 years amounts to some 18 million of cubic meters (Mm3) per year. Consequently, the water balance calculated is clearly negative, which is evidenced as a notable consumption of water reserves ( $-13 \mathrm{Mm} 3$ per year and a current accumulated drawdown exceeding $350 \mathrm{Mm}^{3}$ ). In some parts, groundwater heads have fallen by up to $200 \mathrm{~m}$ over a period of 30 years, with a depletion rate over $10 \mathrm{~m} / \mathrm{year}$ in some sectors of the aquifers. Recently, measures have been taken to alleviate the water problems of the region aimed to alleviate the imbalance of aquifer water budgets. Among others, stands out the import of domestic water through Tajo-Segura transfer to supply the main cities (Jumilla and Yecla), with an urban demand of about six million of cubic meters per year. Only Jumilla has finally asked for its inclusion on the Mancomunidad de los Canales del Taibilla (MCT). Another important intervention is the consideration of replacing groundwater extraction rights by water rights from desalination. However, the possibility of returning the aquifers to their original condition have yet to be considered, let alone any time scale or estimation of the costs and benefits involved. 
A lumped recharge model (Molina et al., 2009, 2011, 2013) was calibrated using the Visual-Balan tool (Samper et al. 1999, 2005). This is a hydrological model, developed by the University of La Coruña (Spain), which solves the water balance equations in the soil, the unsaturated zone and the aquifer. It requires only a small number of parameters, all of which can be estimated with reasonable accuracy, or easily measured. The model incorporates user-friendly interfaces to input data and post-process results. Taking into account that recharge is a non-linear process and that the results are very sensitive to the time-scale used, this model has the advantage that it can operate on a daily scale. It evaluates hydrological components in a sequential way and allows computation of daily groundwater levels, as well as groundwater discharge rates. The model is calibrated by minimizing the differences between the measured and simulated heads and stream-aquifer interaction flows. Visual-Balan takes irrigation sources and return flows into account. It also considers snowfall precipitation, snowmelt and runoff. Visual-Balan has been successfully applied in many Spanish and South American case studies (Samper et al., 2007; Jimenez et al., 2010; Candela et al, 2012, among others) in a similar way to this investigation. In the present case study, daily precipitation and temperature data were introduced into the model after completing a time series analysis using data from neighbouring meteorological stations and for the considered RCM. The main soil parameters were: root zone thickness $(0.5 \mathrm{~m})$, total porosity $(8 \%)$, wilting point $(3 \%)$, field capacity $(7 \%)$, vertical hydraulic conductivity $(0.08$ $\mathrm{m} /$ day) and Useful Water Reserve (UWR) rate $(20 \mathrm{~mm})$. The main parameters for the vadose zone were: depletion coefficient for subsurface flow 0.006 (1/day); vertical hydraulic conductivity (1000 (mm/day); depletion coefficient for aquifer recharge 0.6931 (1/day). Initial moisture was zero $(0 \mathrm{~mm})$. Finally, the main parameters of the saturated zone were: depletion coefficient: 0.0035 (1/day); storage coefficient: 0.02; aquifer initial head: $475(\mathrm{~m})$; aquifer discharge head: $475(\mathrm{~m})$. We have assumed that the parameters representing the hydrologic cycle for recharge are stationary (i.e., they will not change in the future). The water-table-fluctuation method was used to estimate aquifer recharge. Calibration of the model was performed by comparing the observed and simulated groundwater heads at a similar, neighbouring aquifer (El Cantal). This assumption was made because this aquifer remains unexploited and consequently, under a natural regime, the piezometric level variations are due solely to inflows of natural 
recharge. The calibrated model was used to obtain a daily future recharge series from data series of future precipitation and temperature obtained by perturbing the historical series.

\section{ASSESSMENT OF CLIMATE CHANGE IMPACT ON THE SERRAL-SALINAS AQUIFER}

\subsection{Analysis of RCM projections and models ensembling}

We extracted information for the study area from a number of different RCM simulations of A1B (using the MPIMET GCM and 7 RCMs included in the ENSEMBLES project, 2009) and A2 emission scenarios (using the HadAM3H GCM and 7 RCMs included in the PRUDENCE project, 2004). To simulate future scenarios using these RCMs, they must first be calibrated to reproduce the statistics on which it is intended to assess the impact of climate change. The goodness of calibration of the RCM projections is assessed by studying their predictions of firstand second-order historical statistics for precipitation, $\mathrm{P}$, and temperature, T, time series. The information corresponding to the control series of each model was compared to the historical series (downloaded from http://badc.nerc.ac.uk/data/cru/) for the period 1961-1990.

The historical data series and control simulations are available at a spatial scale of tens of kms. In order to generate $\mathrm{P}$ and $\mathrm{T}$ time series as input to an aggregated rainfall-runoff model, single series for the historical and control scenarios of each model were used as representative for the system. The historical and control data for each RCM were obtained by weighting the values associated with each cell according to the surface area of the aquifer located within it. The Figure 3 shows the outline of the aquifer and the cells of the CRU that were used to download the historical scenario, together with the weights assigned to each cell according to the percentage of the surface area of aquifer located within it.

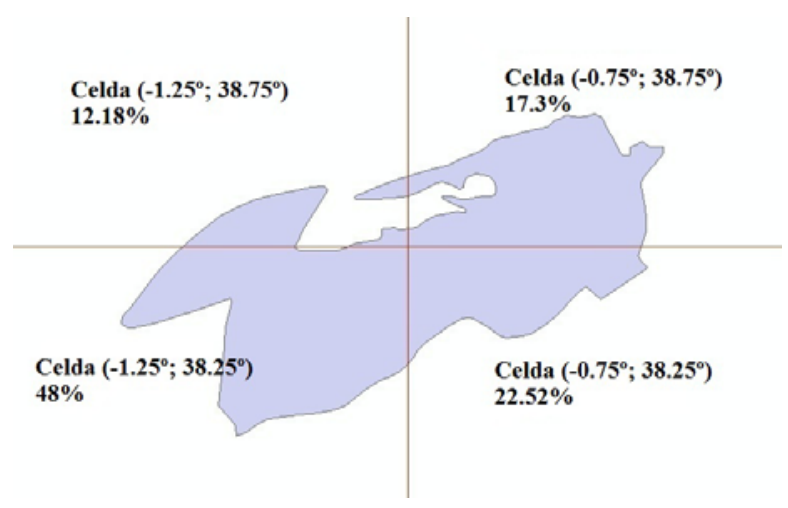


Figura 3. Outline of the Serral Salinas Aquifer, cells of the CRU grid and percentage surface area of the aquifer located in each cell (weights for generating the aggregated series).

Since we are interested in reproducing the changes for an average year for the key monthly statistics (for later use in generating future series), the analysis of the calibrations will focus on these variables. Figure 4 shows the monthly means and standard deviations obtained from the control scenario and the historical series.

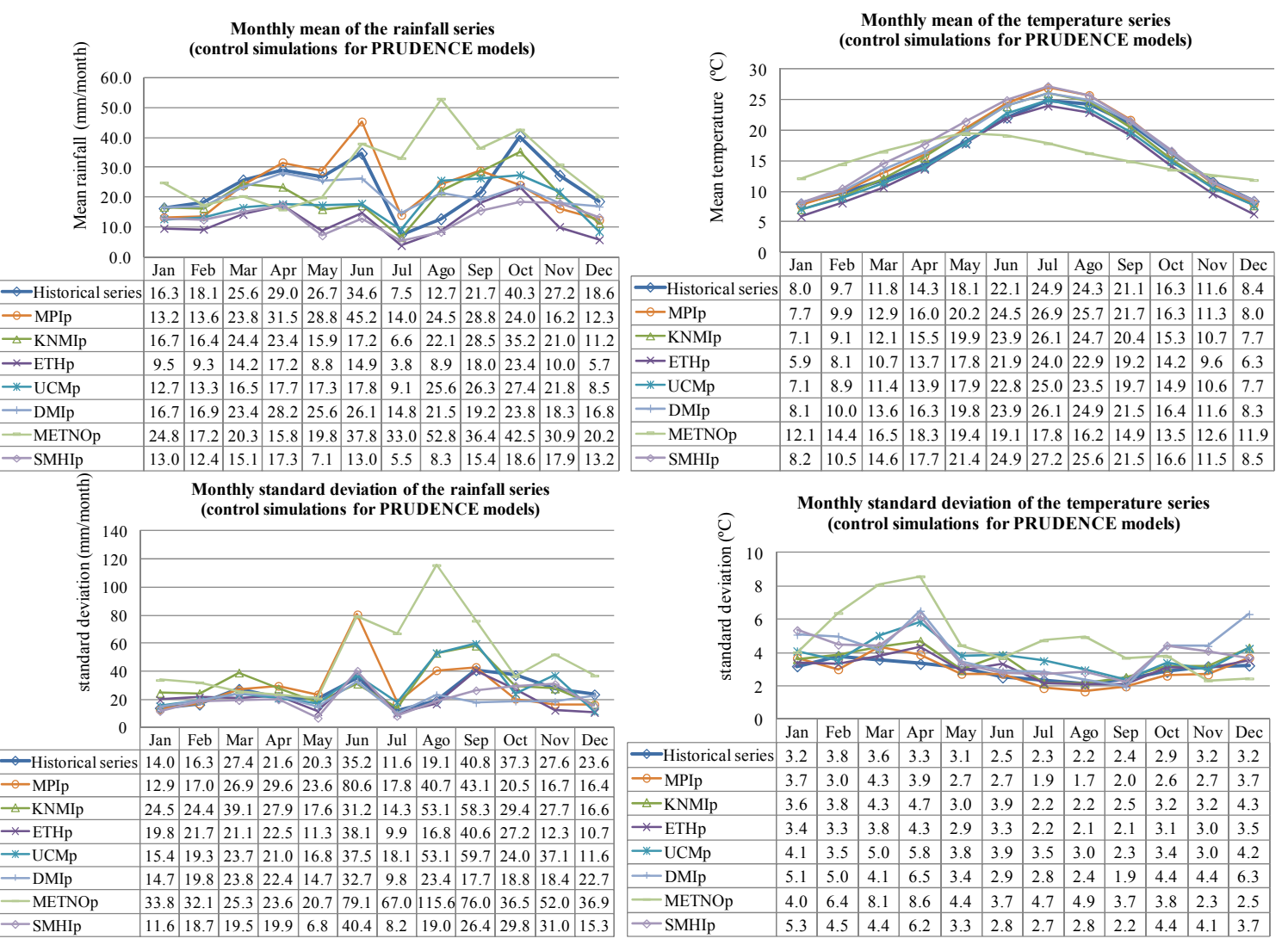

Figure 4. Monthly mean and standard deviation of the historical and control series (rainfall and temperature) for a mean year in the period 1961-1990. PRUDENCE RCMs. 

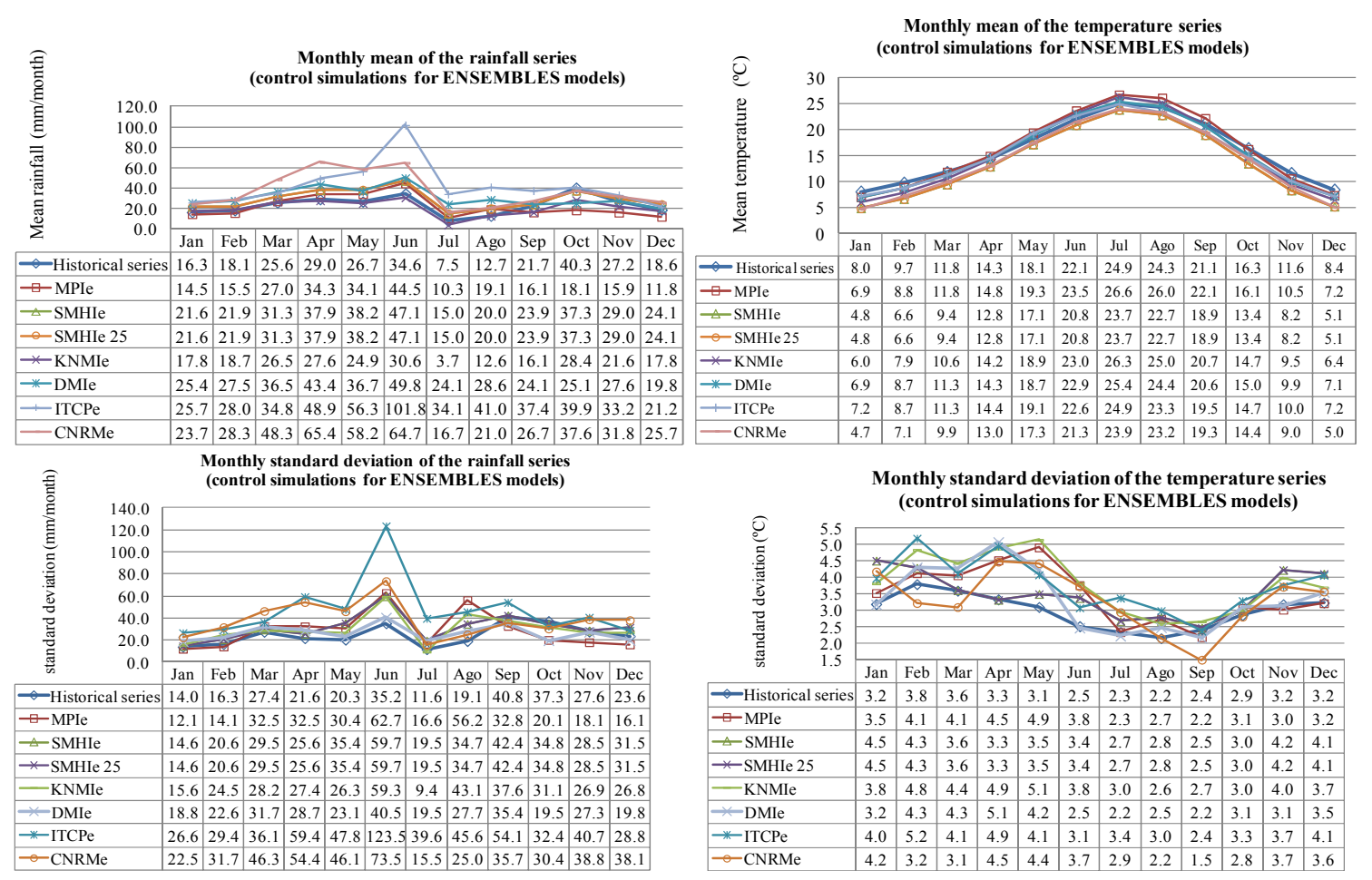

Figure 5. Monthly mean and standard deviation of the historical and control series (rainfall and temperature) for a mean year in the period 1961-1990. ENSEMBLE RCMs

Figures 4 and 5 show how the models were able to reproduce reasonably well the $\mathrm{T}$ and $\mathrm{P}$ statistics on a monthly basis, with the exception of METNOp model, the MPIPp model (downloaded from PRUDENCE, 2004), and the ITCPe and CNRMe models (downloaded from ENSEMBLES, 2009). Average temperatures are reproduced with minor differences from the historical series, except for METNOp. Differences in standard deviations for temperature series are somewhat greater, but otherwise they captured the annual evolution reasonably well,except the already mentioned METNOp. Greater differences between the control scenario (for each $\mathrm{RCM}$ ) and the historic series were observed for average rainfall. Most of the RCMs estimated the statistics of the precipitation time series reasonably well but not the PRUDENCE METNOp or MPIP models, nor the ENSEMBLE CNRMe and ITCPe models, which also showed major differences in the standard deviations.

As proposed in section 2.1, the methodology for synthesising the goodness of fit obtained involved the calculation of the Id index defined as the sum (over the twelve months of an average 
year) of the absolute value of the relative difference between the statistics of the time series and the control scenario. Table 1 shows the results summarising the goodness-of-fit of each RCM on a monthly scale derived from the results in Figures 4 and 5 and on a daily scale, for which the standard deviation is obviously different from the monthly one.

\begin{tabular}{|c|c|c|c|c|c|c|c|c|}
\hline \multicolumn{9}{|c|}{ RCMs for the A1B scenario (ENSEMBLES MODELS) } \\
\hline & \multicolumn{4}{|c|}{ daily series } & \multicolumn{4}{|c|}{ monthly series } \\
\hline & \multicolumn{2}{|c|}{ Rainfall } & \multicolumn{2}{|c|}{ Temperature } & \multicolumn{2}{|c|}{ Rainfall } & \multicolumn{2}{|c|}{ Temperature } \\
\hline & Id $(\Delta x)$ & Id $(\Delta \sigma)$ & Id $(\Delta x)$ & Id $(\Delta \sigma)$ & Id $(\Delta x)$ & Id $(\Delta \sigma)$ & Id $(\Delta x)$ & Id $(\Delta \sigma)$ \\
\hline CNRMe (*) $(* *)$ & 7.93 & 5.79 & 1.93 & 1.56 & 7.93 & 8.09 & 1.93 & 2.77 \\
\hline DMIe & 6.84 & 4.76 & 0.78 & 1.21 & 6.84 & 3.41 & 0.78 & 1.74 \\
\hline KNMIe & 1.71 & 5.71 & 1.25 & 2.15 & 1.71 & 3.75 & 1.25 & 3.35 \\
\hline SMHIe & 3.96 & 3.22 & 2.22 & 3.30 & 3.96 & 3.96 & 2.22 & 2.12 \\
\hline SMHIe 25 & 3.96 & 3.22 & 2.22 & 3.30 & 3.96 & 3.96 & 2.22 & 2.12 \\
\hline MPIe & 3.52 & 4.34 & 0.82 & 1.07 & 3.52 & 5.91 & 0.82 & 2.25 \\
\hline $\operatorname{ITCPe}(*)(* *)$ & 12.05 & 4.43 & 0.84 & 2.86 & 12.05 & 12.57 & 0.84 & 3.21 \\
\hline \multicolumn{9}{|c|}{ RCMs for the A2 scenario (PRUDENCE MODELS) } \\
\hline & \multicolumn{4}{|c|}{ daily series } & \multicolumn{4}{|c|}{ monthly series } \\
\hline & \multicolumn{2}{|c|}{ Rainfall } & \multicolumn{2}{|c|}{ Temperature } & \multicolumn{2}{|c|}{ Rainfall } & \multicolumn{2}{|c|}{ Temperature } \\
\hline & Id $(\Delta x)$ & Id $(\Delta \sigma)$ & Id $(\Delta x)$ & Id $(\Delta \sigma)$ & Id $(\Delta x)$ & Id $(\Delta \sigma)$ & Id $(\Delta x)$ & Id $(\Delta \sigma)$ \\
\hline MPIp (*) & 4.23 & 5.45 & 0.73 & 22.19 & 4.23 & 4.82 & 0.73 & 1.92 \\
\hline $\mathrm{UCMp}(*)(* *)$ & 4.56 & 8.79 & 0.66 & 13.01 & 4.56 & 4.70 & 0.66 & 3.74 \\
\hline DMIp & 3.10 & 4.36 & 0.62 & 2.56 & 3.10 & 2.60 & 0.62 & 4.66 \\
\hline ЕТНр & 5.71 & 4.08 & 1.33 & 15.42 & 5.71 & 3.19 & 1.33 & 1.38 \\
\hline KNMIp (*) & 3.21 & 4.68 & 0.79 & 16.00 & 3.21 & 5.16 & 0.79 & 1.91 \\
\hline $\begin{array}{l}\text { METNOp (*) } \\
(* *)\end{array}$ & 9.06 & 13.05 & 3.71 & 3.01 & 9.06 & 15.96 & 3.48 & 8.32 \\
\hline SMHIp & 4.76 & 3.53 & 1.09 & 20.98 & 4.76 & 2.83 & 1.09 & 3.67 \\
\hline
\end{tabular}

Table 1. Indices (Id) representative of the distance between the means and standard deviations of historical and control scenarios. Note: the eliminated models (those yielding the poorest calibration for the daily $(*)$ and monthly $(* *)$ series) are highlighted.

Subsequently, we conducted a multi-objective analysis to compare all models to each other in order to eliminate those that calibrated worst. For the ENSEMBLES models on a daily scale the ITCPe and CNRMe were eliminated as being "inferior" to the MPIe and DMIe, 
respectively. In the case of the monthly scale, these two were also eliminated as being "inferior" to DMIe. In the case of the PRUDENCE models, MPIp, UCMp, KNMIp and METNOp, were "inferior" to DMIp on a daily scale, while on a monthly scale, METNOp and UCMp were removed as being "inferior" to ITCPp and MPIp, respectively.

Having eliminated the inferior projections, the final selection was used to calculate the global index (Ib') by summing the four Ip indices for each model (mean and standard deviation for both precipitation and temperature). This index was rescaled and redefining as index $\mathrm{Ib}^{*}$, in which the sum of the values obtained for all models for a given emission scenario is equal to 1 . This was done both for the PRUDENCE models used to simulate emission scenarios A2, and the ENSEMBLES models used for the A1B scenarios. The complementary values of the index Ib*, (1-Ib*) rescaled to 1 (index $\mathrm{Ib}$ ) was then used as the weight to apply to the series obtained with each model create an ensemble of predictions in which the better calibrated models have a greater influence, i.e., the models producing simulations closest to the historical series. Table 2 presents the $\mathrm{Ib}$ indices for each model selected.

\begin{tabular}{|c|c|c|}
\hline \multicolumn{3}{|c|}{ RCMs for the A1B scenario (ENSEMBLES MODELS) } \\
\hline & Ib (daily series) & Ib (monthly series ) \\
\hline CNRMe & - & - \\
\hline DMIe & 0.21 & 0.21 \\
\hline KNMIe & 0.20 & 0.20 \\
\hline SMHIe & 0.19 & 0.19 \\
\hline SMHIe 25 & 0.19 & 0.19 \\
\hline MPIe & 0.21 & 0.21 \\
\hline ITCPe & - & - \\
\hline IIb & 1.00 & 1.00 \\
\hline RCMs for the A2 scenario (PRUDENCE MODELS) \\
\hline & Ib (daily series) & Ib (monthly series ) \\
\hline MPIp & - & 0.20 \\
\hline UCMp & - & - \\
\hline DMIp & 0.34 & 0.21 \\
\hline ETHp & 0.33 & 0.19 \\
\hline KNMIp & - & 0.20 \\
\hline METNOp & - & - \\
\hline SMHIp & 0.33 & 1.00 \\
\hline LIb & 1.00 & \\
\hline
\end{tabular}


Table 2. Ib indices representative of the distance between the means and standard deviations of the historical time series and the control scenario. Note: values from the eliminate models are not given.

Although the ensemble of models allows a more condensed way of presenting the expected impacts on hydrological recharge as a result of climate change, the analysis of the impacts on recharge was not limited to considering only the aggregated projection. The predictions made with each of the RCMs considered were also evaluated, allowing a more complete analysis of the variability and the range of values encompassed by the climate change predictions.

\subsection{Downscaling and generation of future long-term (2071-2100) series for $P$ and $T$}

Information regarding the various RCM simulations allows the expected changes in the mean and standard deviation to be determined for the period 2071-2100 compared to the period 1961-1990. These results, obtained under two emission scenarios (A1B and A2) were used to alter the precipitation and temperature series by applying the procedure outlined in section 2.1 . Future series were generated on a daily scale by altering daily series available for the case study area using the variations in mean and standard deviation expected for the study area. Two alternatives were considered for altering the original historical series: (A) on a daily scale, by correcting the time series according to variations in daily means and standard deviations for the average year, and (B) on a monthly scale, by correcting the monthly time series according to monthly variations in mean and standard deviation in the average year and then distributing them according to the daily distribution pattern observed in the historical series.

\section{A) SERIES OBTAINED WORKING ON A DAILY SCALE}

The changes in the mean and standard deviation obtained on a daily scale in an average year based on the differences between the future and control series were used to alter historical series of precipitation and temperature using the proposed methodology. Figure 6 shows the series of future precipitation obtained by applying this methodology for A2 and future temperature series obtained for A2 and A1B scenarios. 
As appreciated from Figure 6, the generated precipitation series includes negative values that arise due to altering a historical series that contains many zeros. The zeros are a feature of daily precipitation data in arid or semiarid climates. Figure 6 shows only the future series for the A2 scenario, but the same problem was obtained for the A1B scenario as well. For the final series to make physical sense, the negative values could be converted into zeros but, logically, this transformation would mean that the changes in mean and standard deviation that we want to impose on the original series would not be preserved; consequently, the precipitation series generated in this way would not represent the impacts of climate change according to the RCMs.

Due to the large number of negative values contained in the transformed series (see Fig. 6), the modification produced in the mean by eliminating them would be significant. In this case, it would be more appropriate to apply the conventional method of using response ratios for a direct correction of the historical rainfall, since this would at least preserve the changes in the means deduced with the RCMs (Zhu et al., 2005). For this reason, working with daily series of rainfall was dropped. However, in the case of temperature, it is feasible to alter the daily time series by incorporating the change in mean and standard deviation accurately. All the models predict the same pattern of temperatures, except the DMIp model. In the latter case, neither could the control series reproduce the pattern of statistics observed for the historical series.
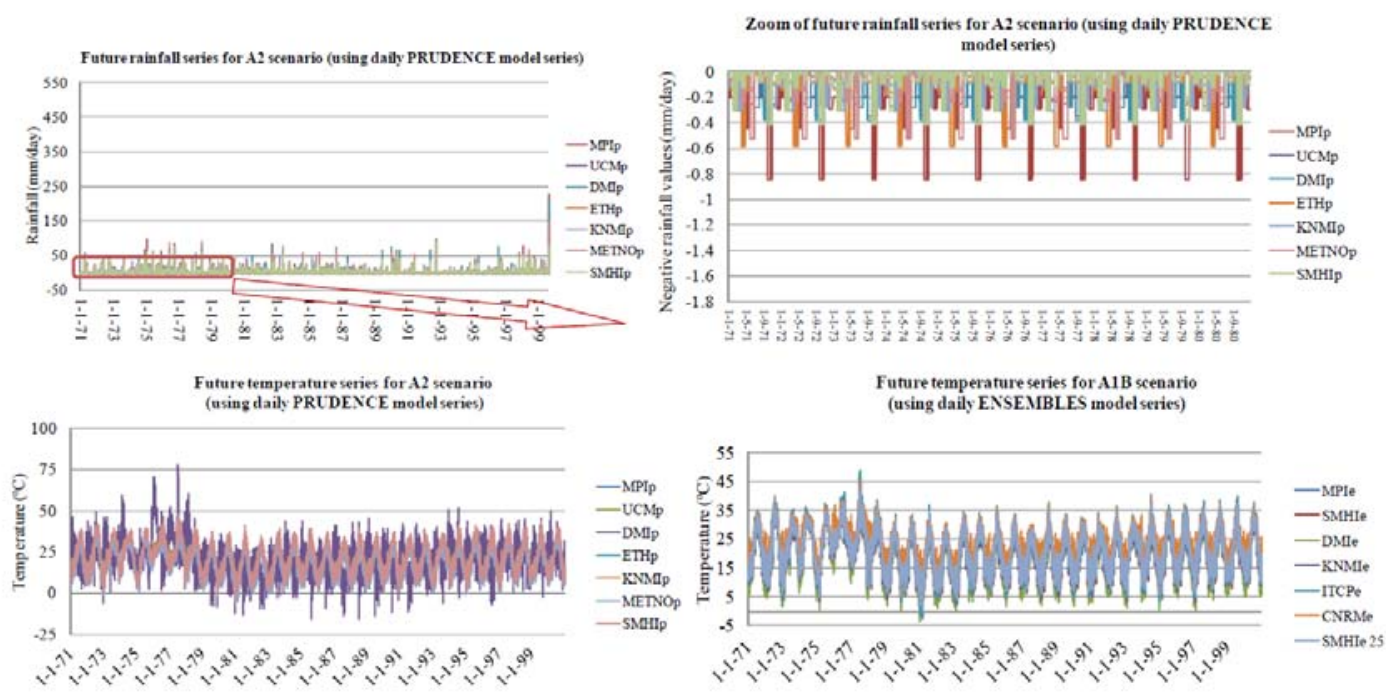

Figure 6. Future series of $\mathrm{P}$ (scenario A2) and $\mathrm{T}$ (scenarios $\mathrm{A} 2$ and $\mathrm{A} 1 \mathrm{~B}$ ) obtained using daily scale data. 


\section{B) SERIES OBTAINED WORKING ON A MONTHLY SCALE}

Due to the problems encountered in altering the precipitation series when working on a daily scale, it was decided to investigate the possibility of modifying the time series according to the variations in mean and standard deviation obtained for the average year on a monthly basis from the control and future series. The daily scale future series could be generated from the monthly series by redistributing the monthly values in accordance with the daily distribution pattern observed in the historical series (the "original climate series" that will be altered to generate the future series). Figure 7 for the A2 emissions scenario and Figure 8 for the A1B emissions scenario show the values for the twelve months of the average year for the future precipitation series generated using our method (labelled "Future Series" in the figures) and monthly response ratios (labelled "Factor Series" in the figures) to translate historical series in the system to future series under Climate change conditions. The results show that, by applying the rescaling methodology to monthly precipitation time series the problem of negative values on the daily scale does not occur because the change in the imposed mean is maintained. The means of the "Future Series" and "Factor Series" coincide, although the standard deviations do not. In this case, the methodology pursued produces an adequate representation of the change in the mean, while at the same time incorporating the change in monthly scale standard deviations. 

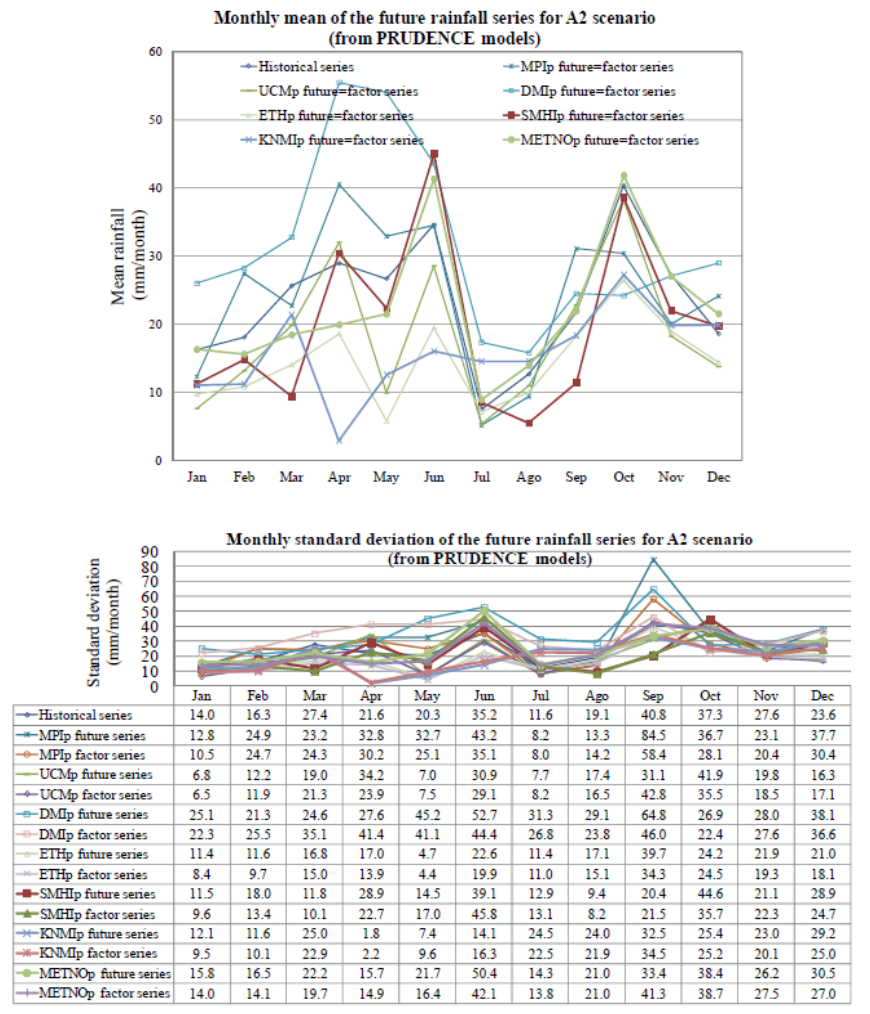

Figure 7. Mean and standard deviation of future precipitation series for the average year obtained from working at a monthly scale, for the A2 emissions scenario (PRUDENCE projections). 

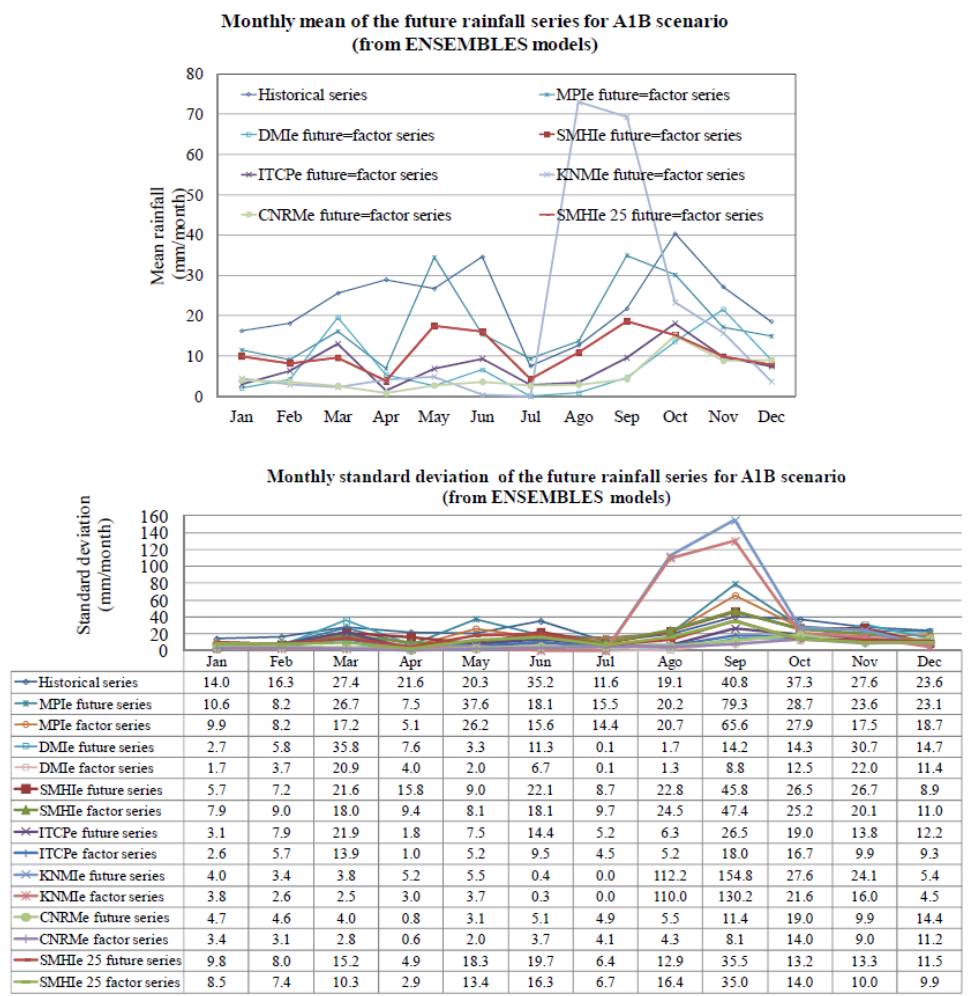

Figure 8. Mean and standard deviation of future precipitation series for the average year obtained from working at a monthly scale, for the A1B emissions scenario (ENSEMBLES projections).

Finally, we calculated the key statistics for the precipitation and temperature series obtained for the A2 (Figure 9) and A1B (Figure 10) scenarios, based on the so-called ensemble of predictions weighting their information according to goodness of calibration using the "Ib" indices of table 2. The ensemble of RCMs predicts an increase in average temperature of $4.5^{\circ} \mathrm{C}$ in the $\mathrm{A} 2$ scenario, and $4^{\circ} \mathrm{C}$ in the A1B scenario. However, there are significant differences in the predictions of the changes in historical precipitation: the A1B ensembled scenario predicts a reduction in mean annual precipitation of $114.4 \mathrm{~mm}$, whereas the A2 ensembled scenario reduces the mean annual precipitation in $22 \mathrm{~mm}$. 

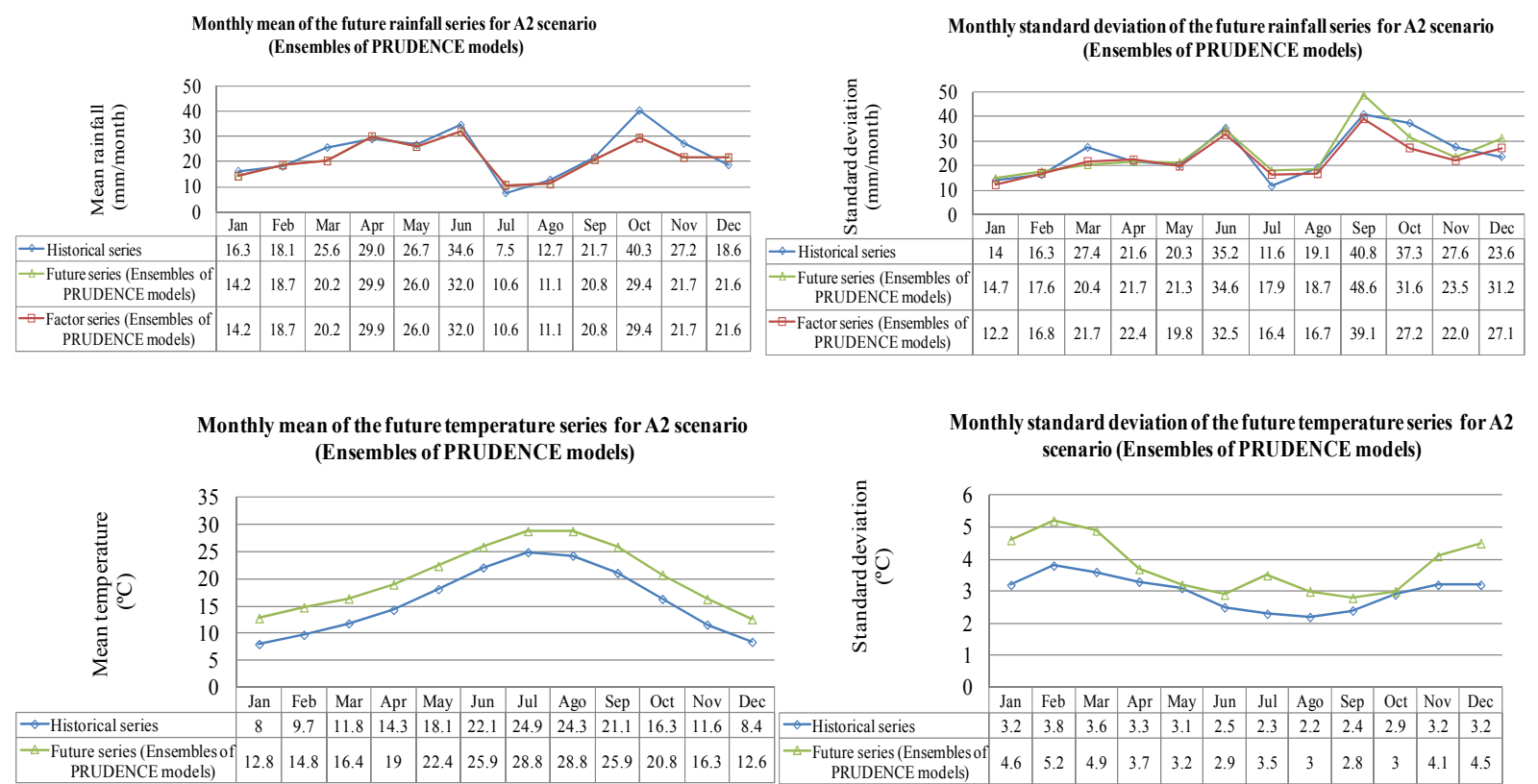

Figure 9. Mean and standard deviation of future precipitation and temperature series obtained by the ensemble of RCMs, for scenario A2 (PRUDENCE).
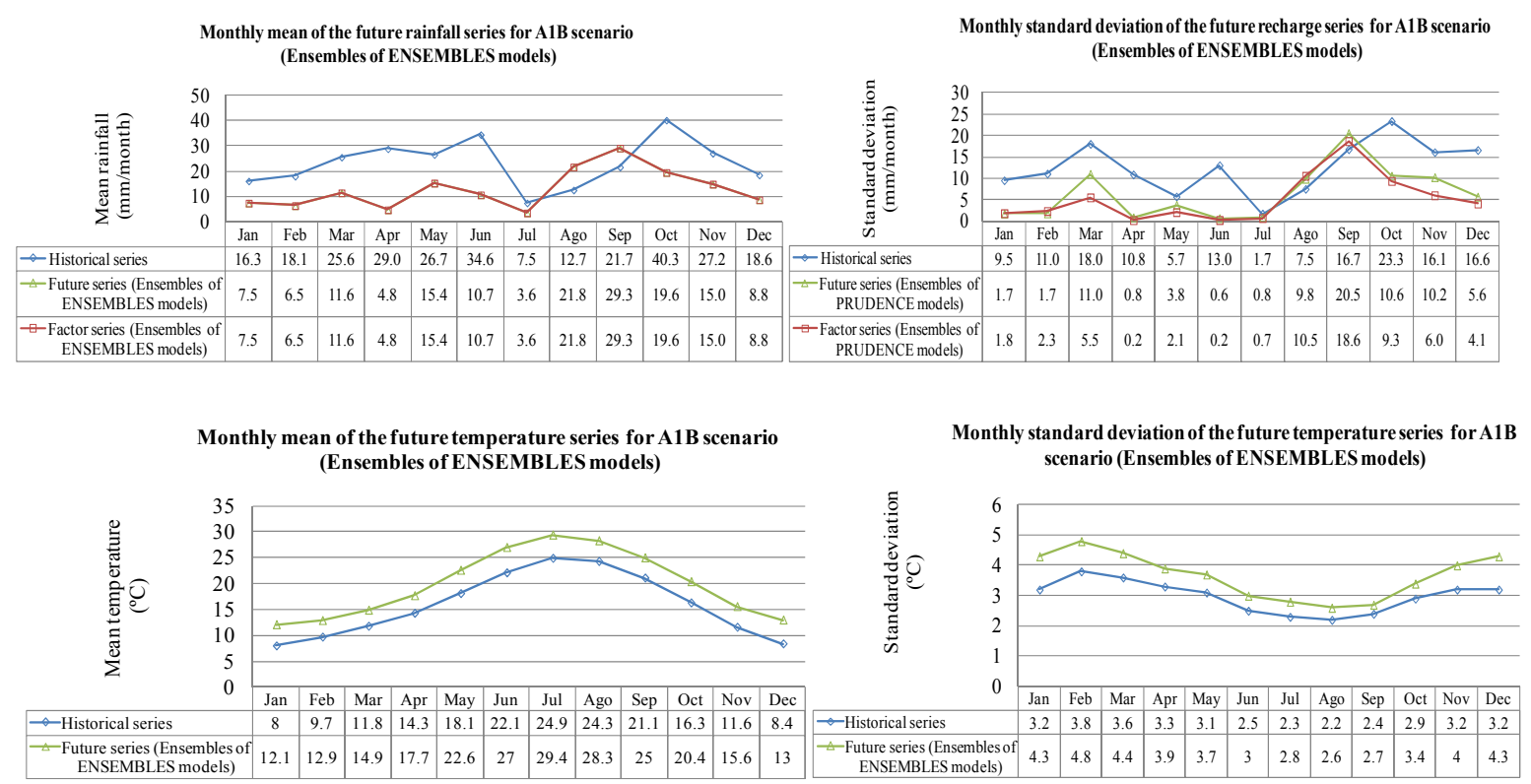

Figure 10. Mean and standard deviation of future precipitation and temperature series obtained by the ensemble of RCMs, for scenario A1B (ENSEMBLES). 


\subsection{Impact of climate change on future recharge scenarios}

To predict aquifer recharge for the period 2071-2100, the newly generated precipitation and temperature series were used as input in the aggregated rainfall-runoff model described in section 3 . The calibrated model was used to produce a daily recharge (Figure 11 for scenario A2 and Figure 12 for scenario A1B).

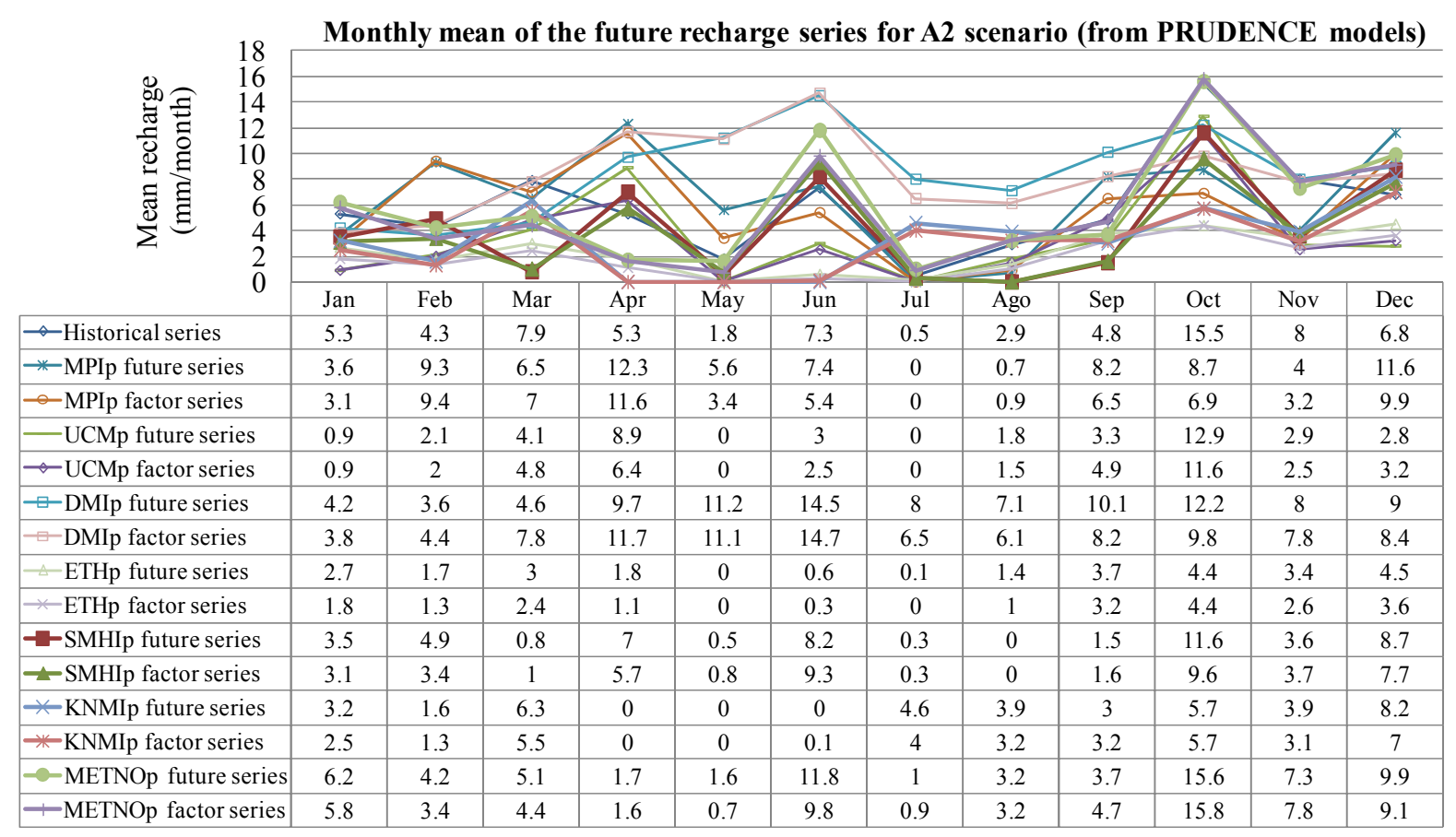

Figure 11. Mean of future recharge series obtained from the various RCMs, for scenario A2 (PRUDENCE). 


\begin{tabular}{l} 
Monthly mean of the future recharge series for A1B scenario (from ENSEMBLES models) \\
\hline
\end{tabular}

Figure 12. Mean of future recharge series obtained from the various RCMs, for scenario A1B (ENSEMBLES).

The results show significant variability between the RCMs employed. Most models predict a reduction in recharge, both for A1B and A2 scenarios. This reduction is clearly seen in Table 3, which includes mean precipitation, temperature and recharge for the historical and predicted time series using the two methodologies to generate future scenarios. Significant increases in recharge are predicted only by one of these RCMs, the DMIp model in the A2 scenario. It is important to note that the results are sensitive to the method used to generate the series.

There were differences between the recharge deduced from the RCMs by altering the historical precipitation and temperature series when only a change in mean was imposed ("Future Series") compared to imposing changes in both the mean and standard deviation ("Factor Series"). In the latter case, by imposing the increased variability expected in the future, there would be a greater number of significant events and therefore an increase in the number of recharge events due to in more occasions the precipitation exceeds the threshold required for generating recharge. Accordingly, when only the change in mean is imposed, the recharge under 
climate change is underestimated by comparison. For example, the average recharge obtained with the MPIp model when only the means of the climate series are corrected would be less even than the historical; in contrast, by incorporating the changes in both the mean and the standard deviation, the predicted recharges exceeded the historical. These results show important uncertainties related with the approach for the recharge process and the future projections, which will be described in the next sections (limitations).

For some projections (e.g., the METNOp model), even when the projected average precipitation is less than the historic, the incorporation of the change in the variability of the climate times series produces a recharge that is slightly higher than the historical. This example shows how, in semiarid regions, even if climate change produced a reduction in rainfall, aquifer recharge could be maintained or even increased in some cases because of the greater number of extreme events derived from an increased variance of the time series.

\begin{tabular}{|c|c|c|c|c|}
\hline & & Historical series & Future series & Factor series \\
\hline \multicolumn{5}{|c|}{ PRUDENCE models } \\
\hline \multirow{3}{*}{ MPIp model } & Mean rainfall (mm/year) & 278.3 & 290.6 & 290.6 \\
\hline & Mean temperature $\left({ }^{\circ} \mathrm{C}\right)$ & 15.91 & 19.88 & 19.88 \\
\hline & Mean recharge ( $\mathrm{mm} /$ year) & 70.3 & 77.9 & 67.3 \\
\hline \multirow[t]{3}{*}{ UCMp model } & Mean rainfall (mm/year) & 278.3 & 220.7 & 220.7 \\
\hline & Mean temperature $\left({ }^{\circ} \mathrm{C}\right)$ & 15.91 & 20.15 & 20.15 \\
\hline & Mean recharge ( $\mathrm{mm} /$ year) & 70.3 & 42.5 & 40.3 \\
\hline \multirow[t]{3}{*}{ DMIp model } & Mean rainfall (mm/year) & 278.3 & 378.2 & 378.2 \\
\hline & Mean temperature $\left({ }^{\circ} \mathrm{C}\right)$ & 15.91 & 21.08 & 21.08 \\
\hline & Mean recharge ( $\mathrm{mm} /$ year) & 70.3 & 102.2 & 100.2 \\
\hline \multirow{3}{*}{ ETHp model } & Mean rainfall (mm/year) & 278.3 & 173.7 & 173.7 \\
\hline & Mean temperature $\left({ }^{\circ} \mathrm{C}\right)$ & 15.91 & 21.03 & 21.03 \\
\hline & Mean recharge ( $\mathrm{mm} /$ year) & 70.3 & 27.3 & 21.8 \\
\hline \multirow{3}{*}{ KNMIp model } & Mean rainfall (mm/year) & 278.3 & 189.6 & 189.6 \\
\hline & Mean temperature $\left({ }^{\circ} \mathrm{C}\right)$ & 15.91 & 19.98 & 19.98 \\
\hline & Mean recharge ( $\mathrm{mm} /$ year) & 70.3 & 40.5 & 35.7 \\
\hline \multirow[t]{3}{*}{ METNOp model } & Mean rainfall (mm/year) & 278.3 & 268.2 & 268.2 \\
\hline & Mean temperature $\left({ }^{\circ} \mathrm{C}\right)$ & 15.91 & 18.05 & 18.05 \\
\hline & Mean recharge ( $\mathrm{mm} /$ year) & 70.3 & 71.3 & 67.1 \\
\hline \multirow[t]{3}{*}{ Modelo SMHIp } & Mean rainfall (mm/year) & 278.3 & 238.8 & 238.8 \\
\hline & Mean temperature $\left({ }^{\circ} \mathrm{C}\right)$ & 15.91 & 22.26 & 22.26 \\
\hline & Mean recharge ( $\mathrm{mm} /$ year) & 70.3 & 50.5 & 46 \\
\hline \multicolumn{5}{|c|}{ ENSEMBLES models } \\
\hline \multirow[t]{3}{*}{ MPIe model } & Mean rainfall (mm/year) & 278.3 & 213.6 & 213.6 \\
\hline & Mean temperature $\left({ }^{\circ} \mathrm{C}\right)$ & 15.91 & 19.47 & 19.47 \\
\hline & Mean recharge ( $\mathrm{mm} /$ year) & 70.3 & 44.5 & 35.1 \\
\hline \multirow[t]{3}{*}{ SMHIe model } & Mean rainfall (mm/year) & 278.3 & 131.8 & 0.49 \\
\hline & Mean temperature $\left({ }^{\circ} \mathrm{C}\right)$ & 15.91 & 19.61 & 19.61 \\
\hline & Mean recharge ( $\mathrm{mm} /$ year) & 70.3 & 28 & 24.9 \\
\hline \multirow[t]{3}{*}{ DMIe model } & Mean rainfall (mm/year) & 278.3 & 90.2 & 0.25 \\
\hline & Mean temperature $\left({ }^{\circ} \mathrm{C}\right)$ & 15.91 & 18.99 & 18.99 \\
\hline & Mean recharge ( $\mathrm{mm} /$ year) & 70.3 & 20.1 & 10.7 \\
\hline \multirow{3}{*}{ KNMIe model } & Mean rainfall (mm/year) & 278.3 & 203.9 & 0.56 \\
\hline & Mean temperature $\left({ }^{\circ} \mathrm{C}\right)$ & 15.91 & 20.16 & 20.16 \\
\hline & Mean recharge ( $\mathrm{mm} /$ year) & 70.3 & 46.5 & 42.8 \\
\hline \multirow[t]{3}{*}{ ITCPe model } & Mean rainfall (mm/year) & 278.3 & 139.6 & 139.6 \\
\hline & Mean temperature $\left({ }^{\circ} \mathrm{C}\right)$ & 15.91 & 21.79 & 21.79 \\
\hline & Mean recharge ( $\mathrm{mm} /$ year) & 70.3 & 9.6 & 4.8 \\
\hline \multirow[t]{3}{*}{ CNRMe model } & Mean rainfall (mm/year) & 278.3 & 87.4 & 87.4 \\
\hline & Mean temperature $\left({ }^{\circ} \mathrm{C}\right)$ & 15.91 & 24.11 & 24.11 \\
\hline & Mean recharge ( $\mathrm{mm} /$ year) & 70.3 & 3.2 & 2.7 \\
\hline \multirow{3}{*}{ SMHIe 25 model } & Mean rainfall (mm/year) & 278.3 & 154.7 & 0.36 \\
\hline & Mean temperature $\left({ }^{\circ} \mathrm{C}\right)$ & 15.91 & 20.94 & 20.94 \\
\hline & Mean recharge $(\mathrm{mm} /$ year$)$ & 70.3 & 9.9 & 8.2 \\
\hline
\end{tabular}


Table 3. Mean precipitation, temperature and recharge for the historical series and for various future scenarios estimated from the RCMs. Serral Salinas Aquifer.

Finally, key statistics of the recharge series are shown for the proposed RCM ensemble (Figure 13, scenario A2; and Figure 14, scenario A1B). In the A2 scenario the model ensemble predicts a mean annual drop in aquifer recharge of $9.9 \mathrm{~mm}$, or $-14 \%$ as compared with the historical recharge.

In the A1B scenario, a significantly greater reduction in mean annual recharge is expected $-40.6 \mathrm{~mm}$, which represents a drop of $57.7 \%$ compared to the historical. In both scenarios, the rainfall series obtained by altering both the mean and standard deviation of the historical series result in a higher mean annual recharge than if only the change in the mean is imposed. In this way, by incorporating the higher standard deviation expected in future rainfall scenarios, a greater number of extreme events occur and this feature explains the higher recharge obtained with the proposed methodology, in spite of using the same mean rainfall values. If the expected change in standard deviation of precipitation were not taken into account, this would result in a decrease in recharge in the A2 scenario by $21.8 \%$ (compared to the $14 \%$ obtained when the expected change in standard deviation is imposed). In the A1B scenario, exclusion of the projected change in standard deviation leads to a $65.8 \%$ reduction in average recharge with respect to the historic (compared to a $57.7 \%$ reduction when the change in standard deviation is imposed). Therefore, in this case, we can see how omitting any consideration of the greater number and intensity of extreme events leads to overestimating the reduction in future recharge to the aquifer.
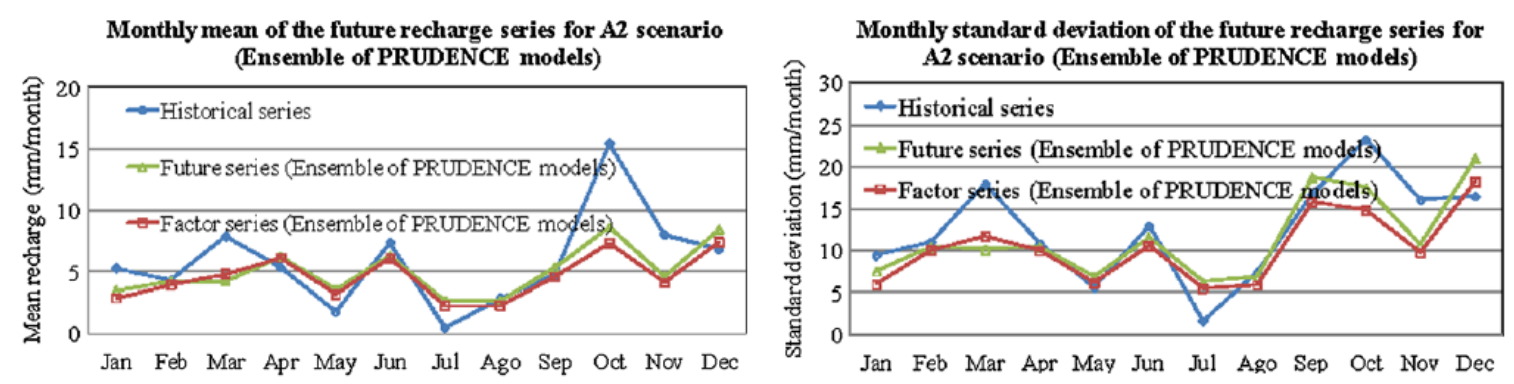

Figura 13. Mean and standard deviation of future recharge series obtained by the ensemble of RCMs for scenario A2 (PRUDENCE). 

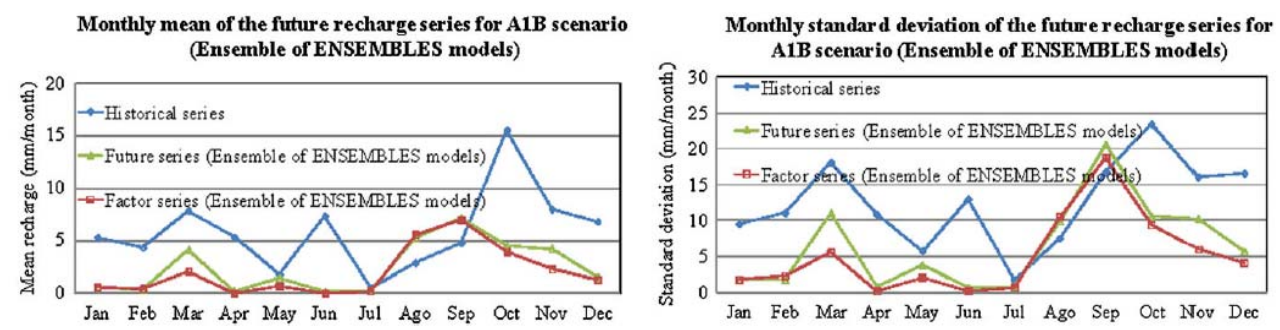

Figure 14. Mean and standard deviation of future recharge series obtained by the ensemble of RCMs for scenario A1B (ENSEMBLES).

\section{LIMITATIONS}

With respect to the methodology tested here, certain limitations have been identified in the evaluation of impacts of climate change, such as:

(1)The use of an aggregated continuous water balance model for evaluating recharge from precipitation and the temperature series does not allow the spatial distribution of the predicted recharge to be assessed, nor does it incorporate any spatial variability in the effects of climate change in different parts of the aquifer. This is in contrast to regional climate models defined on grids with a spatial resolution of tens of kilometers.

(2)The future scenarios are generated from historical series using a procedure that alters the monthly mean and standard deviation according to the change predicted for these variables in the study area. The downscaling method was developed under the assumption that, while the RCM does not provide sufficiently accurate approximations of the absolute value of hydrological variables in a system, they do provide a good approximation for evaluating the relative variation by climate change in the key statistics. We have not incorporated the expected changes in higher-order statistics, only mean and standard deviation, because we also understand the limitations of the future climate projections in order to get further insight on those statistics.

(3)The method is not applicable for modifying time series of variables that cannot physically take negative values and/or with a large number of zeros, for example, rainfall on a daily scale. In 
such cases, the modified series contains many negative numbers and if these are replaced by zeros, the changes in mean and standard deviation imposed a priori are not preserved. Although the objective is to obtain precipitation and temperature series that can then be used as input to a rainfall-runoff model on a daily scale, the problem of negative and zeros led us to modify the time series according to the variations in mean and standard deviation for the average year, but on a monthly basis, i.e., using the monthly control and future series. By doing this, the future series not only incorporates the changes to the mean, but also the changes to the standard deviation on a monthly scale. The future series on a daily scale could be generated from the monthly one by redistributing the monthly values in accordance with the daily distribution pattern observed in the historic series, but it has not been possible to incorporate the modification provoked by climate change in the daily variability).

Finally, it should be mentioned that there is still substantial uncertainty regarding the impacts of climate change on mean precipitation from general circulation models (GCMs). However, there is much greater consensus regarding the extremes of precipitation and temperature, which are projected to become more intense as the global hydrological system itself becomes more extreme (Taylor et al, 2013). Longer droughts may be interspersed with more frequent and intense rainfall events. The dominant source of uncertainty lies in the climate projections derived from GCMs, which typically translate the same emission scenarios into very different climate scenarios, particularly with respect to precipitation. In addition, the Mediterranean area presents different exposures to the rain-bearing maritime winds, since it is a closed basin (Romero et al, 1998).

\section{SUMMARY AND CONCLUSIONS}

We have proposed a method to assess the effect of climate change on groundwater,based on generating climate projections and assessing their impacts on groundwater recharge by simulating the new climate series with a previously calibrated water balance model of the aquifer.

Future climate scenarios were generated based on available historical climate series for the system and from information on the expected climate change impacts in the area, extracted from RCM simulations done as part of European climate change projects. We performed a critical analysis of the available RCMs to assess their ability to reproduce historical climate. The selected models were used to generate future rainfall and temperature series by modifying the 
mean and standard deviation of the historical series in accordance with the predictions of the increase or decrease expected due to by climate change, which are derived from the differences between the future and control series provided by RCMs. The corresponding future groundwater recharge series were generated by simulating the new rainfall and temperature series using a lumped rainfall-runoff model.

The approach was applied to evaluate future recharge (2071-2100) in the Serral-Salinas aquifer under two emission scenarios [A2, A1B]. This case study allowed us to draw the following conclusions about the applicability of the proposed rescaling technique to different variables and time scales: The methodology cannot be applied when altering series of variables that cannot take negative values or which contain a large number of zeros (for example, daily rainfall series). In these cases, the altered series would include many negative values and, if replaced by zeros, the change in mean and standard deviation would not be preserved. In the remaining cases, the methodology works properly, allowing more information to be incorporated than by using a simple average change imposed by the classical method of directly multiplying the time series by a certain factor.

The results indicate significant differences in the recharge predicted for a given scenario depending on the RCM used. We also observe significant differences when generating rainfall and temperature series when both mean and standard deviation are altered, compared to changes only in the mean. Significant differences are observed between these climatic series generated by imposing only the change in the mean (with respect to the historical), as compared to the series generated when the change in standard deviation is also incorporated. An increase in rainfall variability (as expected under future climate change scenarios) could increase recharge rates for a given mean rainfall because the number of extreme events predicted increases. Furthermore, some RCMs predict increases with respect to the historical recharge to the aquifer, even though climate change would produce a reduction in the mean rainfall and an increased mean temperature.

A multi-objective analysis was applied to derive ensemble predictions that confer greater value to the information obtained from the best calibrated models (better approximations of their control time series to the historical records). For the period 2071-2100, this ensemble of predictions estimated a reduction in mean annual recharge (with respect to the historical period 1961-1990) of $14.0 \%(9.9 \mathrm{~mm})$ for scenario A2 and of $57.7 \%$ (40.6 mm) for scenario A1B. 
Lower recharge values were obtained by imposing only the changes in the mean (reductions of $21.8 \%$ for scenario A2; and $65.8 \%$ in scenario A1B).

\section{ACKNOWLEDGEMENTS}

This work has been developed under the framework of the CGL-2009-13238-C02-01 and CGL2009-13238-C02-02 research projects, financed by the Plan Nacional I+D+I 2008-2011 (Ministry of Science and Innovation, Spain). The study was also partially supported by the European Community 7th Framework Project GENESIS (226536) on groundwater systems.We also thank the PRUDENCE and ENSEMBLES Projects, since some public data of this project have been applied.

\section{REFERENCES}

AEMet (2009). Generación de escenarios regionalizados de cambio climático para España. Agencia Estatal de Meteorología, Ministerio de Medio Ambiente y Medio Rural y Marino y Medio Rural y $\quad$ Marino. 158 pp. Available in [www.aemet.es/documentos/es/elclima/cambio_climat/escenarios/Informe_Escenarios.pdf]

Aguilera, H., Murillo, J., 2009. The effect of possible climate change on natural groundwater recharge based on a simple model: a study of four karstic aquifers in SE Spain. Environ. Geol. 57 (5), 963-974.

Barron, O., Pollock, D., Crosbie, R., Dawes, W., Charles, S., Mpelasoka, F., Aryal, S., Donn, M. and Wurcker, B. 2010. The impact of climate change on groundwater resources: The climate sensitivity of groundwater recharge in Australia. CSIRO: Water for a Healthy Country Report to National Water Commission.

Bell, V.A., Kay, A.L., Jones, R.G. and Moore, R.J., 2007. Development of a high resolution gridbased river flow model for use with regional climate model output. Hydrol. Earth Syst. Sci. 11(1), 532-549.

Kløve, B., Ala-Aho, P., Bertrand, G., Gurdak, J.J., Kupfersberger, H., Kværner, J., Muotka, T., Mykrä, H., Preda, E., Rossi, P., Uvo, C.B., Velasco, E., Pulido-Velázquez, M., 2013. Climate 
Change Impacts on Groundwater and Dependent Ecosystems. J. of Hydrology, http://dx.doi.org/10.1016/j.jhydrol.2013.06.037

Bouraoui, F., Vachaud, G., Li, L.Z.X., Le Treut, H., Chen, T., 1999. Evaluation of the impact of climate changes on water storage and groundwater recharge at the watershed scale. Clim. Dynam. 15: 153-161.

Candela, L., Igel, Wv, Elorza, FJ, Aronica, G., 2009. Impact assessment of combined climate and management scenarios on groundwater resources and associated wetland (Majorca, Spain). $J$. Hydrol. 376: 510-527.

Candela, L, Tamoh K, Olivares,G, Gomez, M. 2012. Modelling impacts of climate change on water resources in ungauged and data-scarce watersheds. Application to the Siurana catchment (NE Spain). Science of the Total Environment 440, 253-260.

Cayan, D.R., Maurer, E.P., Dettinger, M.D., Tyree, M., Hayhoe, K., 2008. Climate change scenarios for the California region. Climatic Change 87 (Suppl. 1), S21- S42.

Christensen, NS, Lettenmaier DP, 2009. A multimodel ensemble approach to assessment of climate change impacts on the hydrology and water resources of the Colorado River Basin. Hydrology and Earth System Sciences, 11(4): 1417-1434

Döll, P., 2009. Vulnerability to the impact of climate change on renewable groundwater resources: a global-scale assessment. Environ. Res. Lett. 4 (3), 035006.

Dragoni, W. and Sukhija, B.S., 2008. Climate change and groundwater: a short review. Geological Society, London, Special Publications 2008; v. 288; 1-12.

ENSEMBLES PROJECT, 2009. European Commission's 6th Framework Integrated Project from 2004-2009 (through the contract GOCE-CT-2003-505539) under the Thematic SubPriority "Global Change and Ecosystems" (web site http://ensembles-eu.metoffice.com/).

FAO, 2008. Climate change water and flood security. FAO WATER REPORTS 36. ISBN 97892-5-106795-6

Fowler, H. J., Blenkinsop, S. and C. Tebaldib, 2007. Linking climate change modelling to impacts studies: recent advances in downscaling techniques for hydrological modelling. Int. J. Climatol. 27: 1547-1578. DOI: 10.1002/joc.1556. 
Fowler, HJ; Kilsby, CG; Stunell, J, 2007b. Modelling the impacts of projected future climate change on water resources in north-west England. Hydrology and Earth system Sciences 11 (3): 1115-1124.

Green, T.R., Bates, B.C., Charles, S.P., Fleming, P.M., 2007. Physically based simulation of potential effects of carbon dioxide-altered climates on groundwater recharge. Vadose Zone J. 6 (3): 597-609.

Green, T.R., Taniguchi, M., Kooi, H., Gurdak, J.J., Allen, D.M., Hiscock, K. M., Treidel, H., and Aureli, A. 2011. Beneath the surface of global change: Impacts of climate change on groundwater. J. Hydrol. 405 (2011): 532-560, doi:10.1016/j.jhydrol.2011.05.002

Gurdak, J.J., Roe, C.D., 2010. Review: recharge rates and chemistry beneath playas of the High Plains aquifer, USA. Hydrogeol. J. 18 (8), 1747-1772.

Haylock, M., N. Hofstra, A. K. Tank, E. Klok, P. Jones, and M. New (2008), A European daily high-resolution gridded data set of surface temperature and precipitation for 1950-2006, J. Geophys. Res., 113, D20119, doi:10.1029/2008JD010201.

Hernandez-Barrios, L., 2007. Efectos del cambio climático en los sistemas complejos de recursos hídricos. Aplicación a la cuenca del Júcar. (Effects of climate change on complex water resources systems. Application to the Jucar River Basin.) Ph. D. dissertation, Technical University of Valencia, Spain.

Herrera-Pantoja, M., Hiscock, K.M., 2008. The effects of climate change on potential groundwater recharge in Great Britain. Hydrol. Process. 22 (1), 73-86.

Iglesias A, Garrote L, Flores F, Moneo, M., 2007. Challenges to manage the risk of water scarcity and climate change in the Mediterranean. Water Resour Manage 21:227-288

IPCC, 2007. Four assessment report: Impacts, Adaptation and Vulnerability.

Jiménez-Martínez J, Candela L, Molinero J, Tamoh K. (2010). Groundwater recharge in irrigated semi-arid areas with different crops. Quantitative hydrological modelling and sensitivity analysis. Hydrogeology Journal 18, 1811-1824. 
Jyrkama, M.I., Sykesa, J.F., 2007. The impact of climate change on spatially varying groundwater recharge in the grand river watershed (Ontario). J. Hydrol. 338, 237-250

Kovalevskii, V.S., 2007. Effect of climate changes on groundwater. Water Resour. 34 (2), 140152.

Kundzewicz, Z.W., Mata, L.J., Arnell, N.W., Doll, P., Kabat, P., Jimenez, B., Miller, K.A., Oki, T., Sen, Z., Shiklomanov, I.A., 2007. Freshwater resources and their management. In: Parry, M.L., Canziani, O.F., Palutikof, J.P., van der Linden, P.J., Hanson, C.E. (Eds.), Climate Change 2007: Impacts, Adaptation and Vulnerability. Cambridge University Press, Cambridge, pp. $173-210$.

Lautenbach, S. Berlekamp, J., Graf, N., Seppelt, R., Matthies, M, 2009. Scenario analysis and management options for sustainable river basin management: Application of the Elbe DSS. Environmental Modelling \& Software, 24(1): 26-43.

Lopez, A., F. Fung, M. New, G. Watts, A. Weston, and R. L. Wilby (2009), From climate model ensembles to climate change impacts and adaptation: A case study of water resource management in the southwest of England, Water Resour. Res., 45, W08419, doi:10.1029/2008WR007499.

Merritt, W., Alila, Y., Barton, M., Taylor, B., Cohen, S. \& Neilsen, D., 2006. Hydrologic response to scenarios of climate change in the Okanagan basin, British Columbia', Journal of Hydrology 326, 79-108. 55, 59, 60

JL Molina, D. Pulido-Velázquez, JL García-Aróstegui, M. Pulido-Velázquez, 2013. Dynamic Bayesian Networks as a Decision Support tool for assessing Climate Change impacts on highly stressed groundwater systems. Journal of Hydrology 479 (2013) 113-129. http://dx.doi.org/10.1016/j.jhydrol.2012.11.038.

Molina, J,L., Arostegui, J.L., Bromley, J., Benavente, J., 2011. Integrated assessment of the European WFD implementation in extremely overexploited aquifers through participatory modelling. Water Resour Manage, 25: 3343-3370.

Molina, J.L., García-Aróstegui, J.L., Benavente, J., Varela, C., De la Hera A, López-Geta, J.A., 2009. Aquifers overexploitation in SE Spain: a proposal for the integrated analysis of water management. Water Resour Manag 23:2737-2760. 
Molina, J. L., García Aróstegui, J. L., 2007. Identificación preliminar de impactos del uso intensivo del agua subterránea en el sureste español: Acuífero Serral-Salinas (MurciaAlicante). En Monográfico del Boletín Geológico y Minero sobre la II Semana de Jóvenes Investigadores del IGME, 2007.

Molina, J.L., García Aróstegui, J.L., 2006. Explotación intensiva de acuíferos y sus impactos: caso de estudio del Serral-Salinas (Murcia-Alicante). Boletín Geológico y Minero, 117 (especial, número monográfico: Investigación joven en Ciencias de la Tierra), 597-599. ISSN: 0366-0176. NIPO: 0657-06-001-2.

Parry, M.L., Parry, O.F. Canziani, J.P. Palutikof, P.J., van der Linden, C.E. Hanson, 2007. Climate change 2007: impacts, adaptation and vulnerability. Contribution of Working Group II to the Fourth Assessment Report of the Intergovernmental Panel on Climate Change. Cambridge University Press, Cambridge, United Kingdom and New York, NY, USA.

Pulido-Velazquez, D., Garrote, L., Andreu, J., Martin-Carrasco, FJ, Iglesias, A. 2011. A methodology to diagnose the effect of climate change and to identify adaptive strategies to reduce its impacts in conjunctive-use systems at basin scale. Journal of Hydrology 405: 110122 doi:10.1016/j.jhydrol.2011.05.014.

PRUDENCE PROJECT, 2004. Prediction of Regional scenarios and Uncertainties for defining European climate change risks and effects. The Prudence Projects by the EU through contract EVK2-CT2001-00132 (web site http://prudence.dmi.dk/).

Romero, R., Guijarro, JA, Ramis, C., and Alonso, S., 1998 A 30 years (1964-1993) daily rainfall data base for the Spanish Mediterranean regions: first exploratory study. International Journal of climatology 18: 541-560

Samper, J., Huguet, Ll., Ares, J. y García Vera, M.A. 1999. Manual del usuario del programa VISUAL BALAN v.1.0: Código interactivo para la realización de balances hidrológicos y la estimación de la recarga. Publicación Técnica de ENRESA nº 5/99, Madrid. 205 pp.

Samper J, Huguet Ll, Ares J, García-Vera MA (2005) User's guide VisualBALAN v.2.0: código interactivo para la realización de balances hidrológicos y la estimación de la recarga [VisualBALAN v.2.0: interactive code to establish water balance and aquifer recharge]. Civil Engineering School of A Coruña, A Coruña, Spain, 150 pp

Samper J, García-Vera MA, Pisani B, Varela A, Losada JA, Alvares D (2007). Using hydrological models and geographic information systems for water resources evaluation: GIS- 
VISUAL-BALAN and its application to Atlantic basins in Spain (Valiñas) and Portugal (Serra da Estrela). In: Lobo Ferreira JP, Vieira JMP, editors.Water in Celtic countries: quantity, quality and climate variability, 310. IAHS; 2007. p. 259-266.

Scibek, J., Allen, D.M.,, Cannon, A.J., Whitfield, P.H., 2007. Groundwater-surface water interaction under scenarios of climate change using a high-resolution transient groundwater model. J. Hydrol., 333(2-4); 165-181.

Taylor, Richard G. Bridget Scanlon, Petra Döll, Matt Rodell, Rens van Beek, Yoshihide Wada, Laurent Longuevergne, Marc Leblanc, James S. Famiglietti, Mike Edmunds, Leonard Konikow, Timothy R. Green, Jianyao Chen, Makoto Taniguchi, Marc F. P. Bierkens, Alan MacDonald, Ying Fan, Reed M. Maxwell, Yossi Yechieli, Jason J. Gurdak, Diana M. Allen, Mohammad Shamsudduha, Kevin Hiscock, Pat J.-F. Yeh, Ian Holman \& Holger Treidel (2013) . Ground water and climate change. Nature Climate Change, 3, 322-329, doi:10.1038/nclimate1744.

Vaccaro, J.J., 1992. Sensitivity of groundwater recharge estimates to climate variability and change, Columbia Plateau, Washington. J. Geophys. Res. 97(D3), 2821-2833.

Werner, Adrian D., Qi Zhang, Lijuan Xue, Brian D. Smerdon, Xianghu Li, Xinjun Zhu, Lei Yu, Ling Li. (2013). An Initial Inventory and Indexation of Groundwater Mega-Depletion Cases. Water Resources Management, 27 (2), 507-533

Wigley, T. M. L., Jones, P. D. \& Kelly, P. M., 1986. Empirical climate studies: warm world scenarios and the detection of climatic change induced by radiactively active gases. In: BOLIN, B., DOOS, B. R., JAGER, J.\& WARRICK, R. A. (eds) The Greenhouse Effect, Climatic Change, and Ecosystems. SCOPE series.

WRF, (Water Resources Foundation), 2009. Climate change impacts. In http://www.theclimatechangeclearinghouse.org/ClimateChangeImpacts/ChangesStormIntensity Frequency/Pages/default.aspx

Yusoff, I., Hiscock, K.M., Conway, D., 2002. Simulation of the impacts of Climate change on groundwater resources in eastern England. In: Hiscock, K.M., Rivett, M.O., Davison, R.M. (Eds.), Sustainable Groundwater Development. Geological Survey of London, London, pp. $325-344$.

Zhu T, Jenkins MW, Lund JR,2005. Estimated impacts of climate warming on California water availability under twelve future climate scenarios. J. Water Resour. Plann. Manage. 
41(5):1027-1038. 